\title{
GEOCHEMICAL EXPLORATION FOR METALLIC MINERALS IN THE META- SEDIMENTARY ROCKS OF OGOTUN, IKEJI-ILE AND IPETU, SOUTHWESTERN NIGERIA
}

\author{
Olususi, Joseph Ige ${ }^{1}$ \\ Ayodele, Olusiji \\ Samuel $^{2+}$ \\ Ajigo, Isaac \\ Ominyi $^{3}$
}

\author{
${ }^{1,2, s}$ Department of Applied Geology, The Federal University of Technology, \\ Akure, Nigeria. \\ 'Email: tjosssey94@gmail.com Tel:+234806075390 \\ Email: samuelayodeleolusiji@yahoo.com Tel: +2349080414142 \\ ${ }^{s}$ Email: ioaijgo@futa.edu.ng Tel: +2348032107038
}

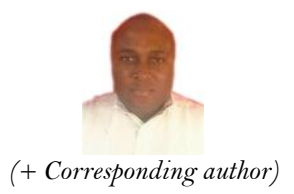

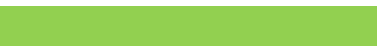

Article History

Received: 22 November 2021 Revised: 27 December 2021

Accepted: 10 January 2022

Published: 20 January 2022

\section{Keywords}

Ogotun

Ikeji-Ile

Ipetu

Geochemistry

Enrichment factor

Mineralization.

\begin{abstract}
The south-eastern part of Ilesha Schist belt which comprises of (Ogotun,Ikeji-Ile and Ipetu-the study area has been totally neglected by previous researchers without any literatures that could serve as clues to mineral exploration in the study area which necessitate this research. Geological mapping was undertaken to determine the underlying rocks followed by systematic sampling at one rock per $3.25 \mathrm{~km}^{2}$, petrographic and geochemical analysis of the rocks. The results of field examination confirmed the existence of migmatite-gneisses, quartzites, quartz-schists, metaconglomerates and porphyritic granites as the dominant rocks while petrographic studies revealed quartz, biotite, feldspar (microcline and plagioclase) and opaque minerals. However, five rocks samples whose thin sections showed opaque minerals were viewed under the reflecting light microscope and a brassy yellow mineral called chalcopyrite was confirmed. Geochemical analytical results revealed that $\mathrm{SiO}_{2}(67.37 \%$ $62.46 \%)$ and $\mathrm{Al}_{2} \mathrm{O}_{3}$ (17.35\%-11.62\%) have higher concentrations, indicating the aluminosilicate nature of the rocks. The trace elemental analysis revealed very high concentrations of $\mathrm{Ba}(2533-10) \mathrm{ppm}$ and $\mathrm{Fe}(55000-4100) \mathrm{ppm}$, followed by moderate to low and very low concentrations of $\mathrm{Cu}(38.40-12.50) \mathrm{ppm}, \mathrm{Pb}$ (.90-39.40) ppm, $\mathrm{Zn}$ (156.00-7.00) ppm, Co (65.20-1.40) ppm, Mn (148.00-981.00) ppm,, As (1.00-3.00) ppm, Th (0.50-10.00) ppm, Rb (311.60-50) ppm ,Cr (1310.-5.00) ppm and U (>0.1-6.3) ppm. Similarly, the principal component analysis (PCA) of the rocks revealed $\mathrm{Cu}-\mathrm{Pb}-\mathrm{Zn}-\mathrm{Mn}-$ Fe mineral associations with $35.24 \%$ also confirmed massive sulphide mineralization. Therefore, the overall results indicated the potentials of the study area to be possibly enriched with other hidden ore deposits and radioactive minerals.
\end{abstract}

Contribution/Originality: This study has been able to unravel the mineralization potentials of the metasedimentary rock units in the study area and discovered that it is enriched with massive sulphide deposits, radioactive and other metallic ore bodies. It is another promising site for detailed mineral exploration.

\section{INTRODUCTION}

The absence of detailed geological/ geochemical information is a major setback to any meaningful, successful mineral exploration and exploitation program in any society. Nigeria's schist belt, being endowed with vast minerals resources (Elueze, 1981) particularly the green stone terrains of the Ilesha schist belt is noted for its gold mineralization and associated metallic minerals deposits. The over dependent on oil and gas coupled with lack of political will mostly by the people at the corridors of power have over shadowed the need to embark on detailed 
geological/geochemical mapping that could be a key to unlocking the vast hidden mineral potentials and exploration prosperity of any nation. Minerals are the foundation for the economic and industrial development of any nation. The study areas (Ogotun, Ikeji-Ile and Ipetu) are considered to be part of Ilesha -Schist belt as they are located in the south-eastern part of the belt. Hence, there is possibility of the study area to host some metallic minerals which are yet to be discovered. The nature and the occurrences of such metallic minerals that may likely be present in the study area could only be unravelled with a detailed mineral exploration program. Many notable researchers have worked on the Ilesha schist belt such as Onougu and Ferrante (1965); Hubbard (1975); Elueze (1981); Abiodun (2011) and Ayodele, Oshin, and Awokunmi (2017). The discovery of gold in Ilesha schist belt could be the gravitating factor that attracted the interest of these researchers to Ilesha schist belt. The aim of this research is to investigate the study area for its mineralisation potentials.

\section{REGIONAL GEOLOGICAL SETTING}

Nigeria lies approximately between latitudes $4^{\circ} \mathrm{N}$ and $15^{\circ} \mathrm{N}$ and Longitudes $3^{\circ} \mathrm{E}$ and $14^{\circ} \mathrm{E}$, within the Pan African mobile belt in between the West African and Congo Cratons. The Nigeria basement complex, forms a part of this Pan-African mobile belt, and lies to the east of the West African Craton and between the Dahomeyan of the Benin Republic at the west and Cameroun at the east (Figure 1). It consists of predominantly Archaean polycyclic grey gneisses of granodioritic to tonalitic composition, remnants of unconformable Proterozoic cover now represented by variably migmatised metasediments which are preserved in syn-collisional schist belts, and many syn-tectonic to late tectonic intrusions (Ajibade, Woakes, \& Rahaman, 1987; McCurry, 1973).

One of the implications of the widely accepted Pan African tectonic model of eastward subduction and continent-continent collision in the southern part of the Trans-Saharan mobile belt is that it generated abundant granitoids in the Nigerian province (Burke, 1972; Olarewaju, 1988; Oyawoye, 1972; Rahaman, 1988). Syntectonic to late tectonic granitoids, diorites and syenites were intruded into both the migmatite-gneiss complexes and overlying supracrustal cover. The intrusions are termed the Older Granites to distinguish them from the Jurassic Younger Granites.

The Nigerian Basement Complex therefore forms a part of the north - south trending orogenic belt which (Ajibade \& Wright, 1989; Grant, 1969) had shown to extend westward into the Benin Republic, Togo, Ghana; eastward into the Cameroon, and northward into Niger Republic. The crystalline rocks which are exposed today rest on a pre-pan African old basement which is the sialic crust, (Turner, 1983).

This rock suite consists of three broad lithological groups: The first is the Polymetamorphic Migmatite-Gneiss complex which is composed largely of migmatite and gneisses of various compositions and amphibolites; also, part of this is the relics of metasedimentary rocks represented by medium to high grade calcareous pelitic and quartzitic rocks occurring within the migmatites and gneisses and they have been described as "Ancient Metasediments", (Rahaman, 1988). Isotopic ages varying from Liberian to Pan - African have been obtained from the rocks.

The second suit of rocks is the Low-grade sediment-dominated schists which form narrow belts in the western half of the country (Figure 2), have been described as "newer metasediments" (Dada \& Rahaman, 1995) and unmigmatized to slightly migmatised shists; (Rahaman, 1988). The third but no less significant group of rocks is the Syntectonic to late tectonic granitic rocks which cut both the migmatite gneiss complex and schist belts. The granitoids include rocks varying in composition from granite to tonalite and charnockite with smaller bodies of syenite and gabbro. Radiometric ages of the granitoids range from 750 - 500 Ma which lie within the Pan - African age spectrum. 

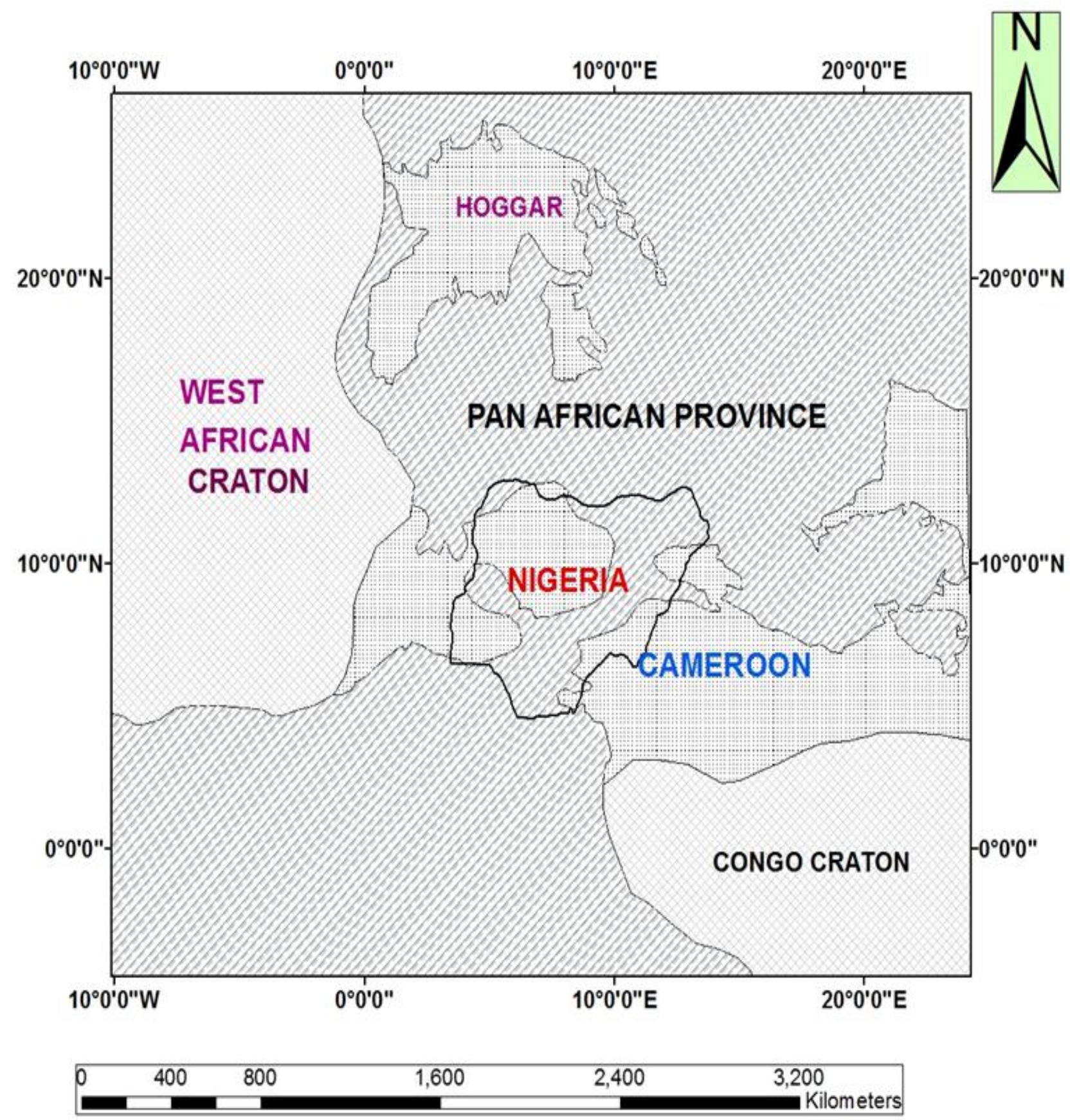

Figure 1. Nigeria within the Pan African Province [Modified after Ajibade and Wright (1988)].

\section{THE STUDY AREA}

The Ife-Ilesha area has been mapped by Hubbard (1975); Ajayi (1981); Rahaman (1988). Two major lithologies, separated into the eastern and western section, by the Ifewara fault system were identified by these authors. The lithology of the eastern section comprises of metasediments dominated by quartz muscovite schist, quartz schist, quartzite, quartzo-feldspathic gneisses and biotite garnet schist. The western lithology consists of volcano sedimentary sequence of pelitic schist, quartzites and metabasites or mylonites. Elueze (1988) and Odeyemi (1993) recognized migmatites, gneisses, amphibolites and metaclastics as the major petrological units in the area. 


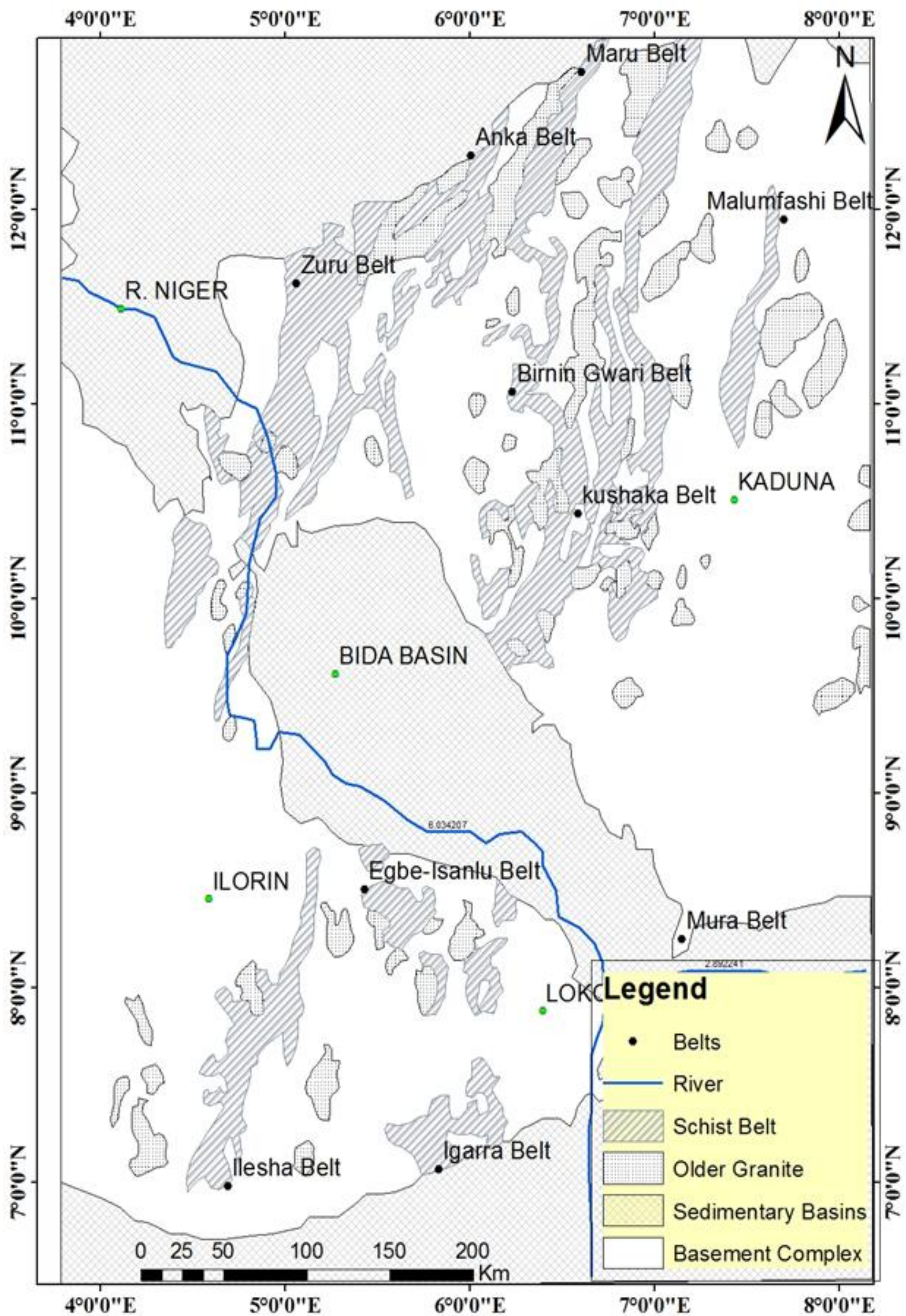

Figure 2. Generalized geological map of Western Nigeria showing distribution of the schist belts, [Modified after Bafor (1988)]. 


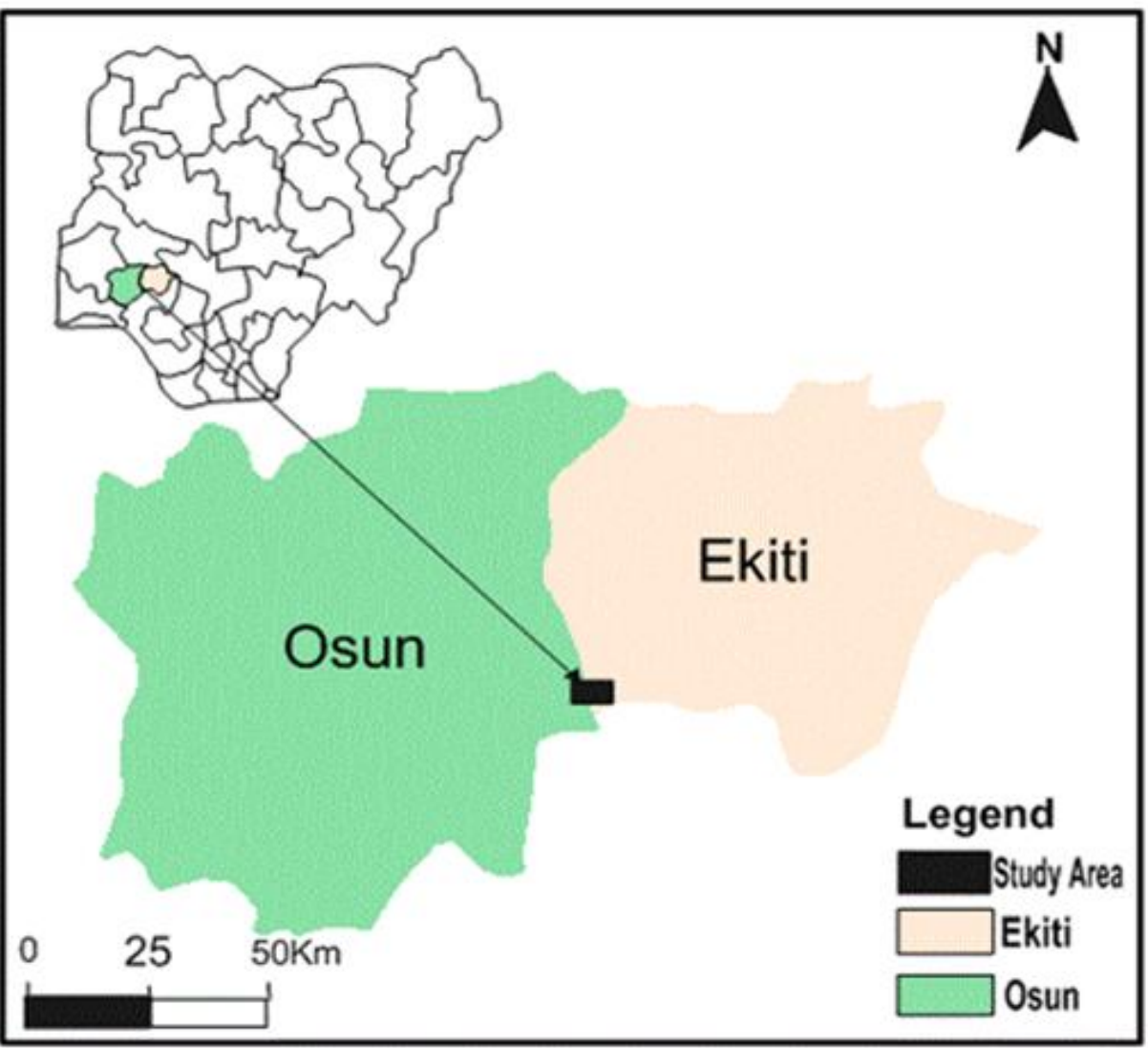

Figure 3. Map of the study area located within Ekiti and Osun States, inset: Map of Nigeria showing the study area.

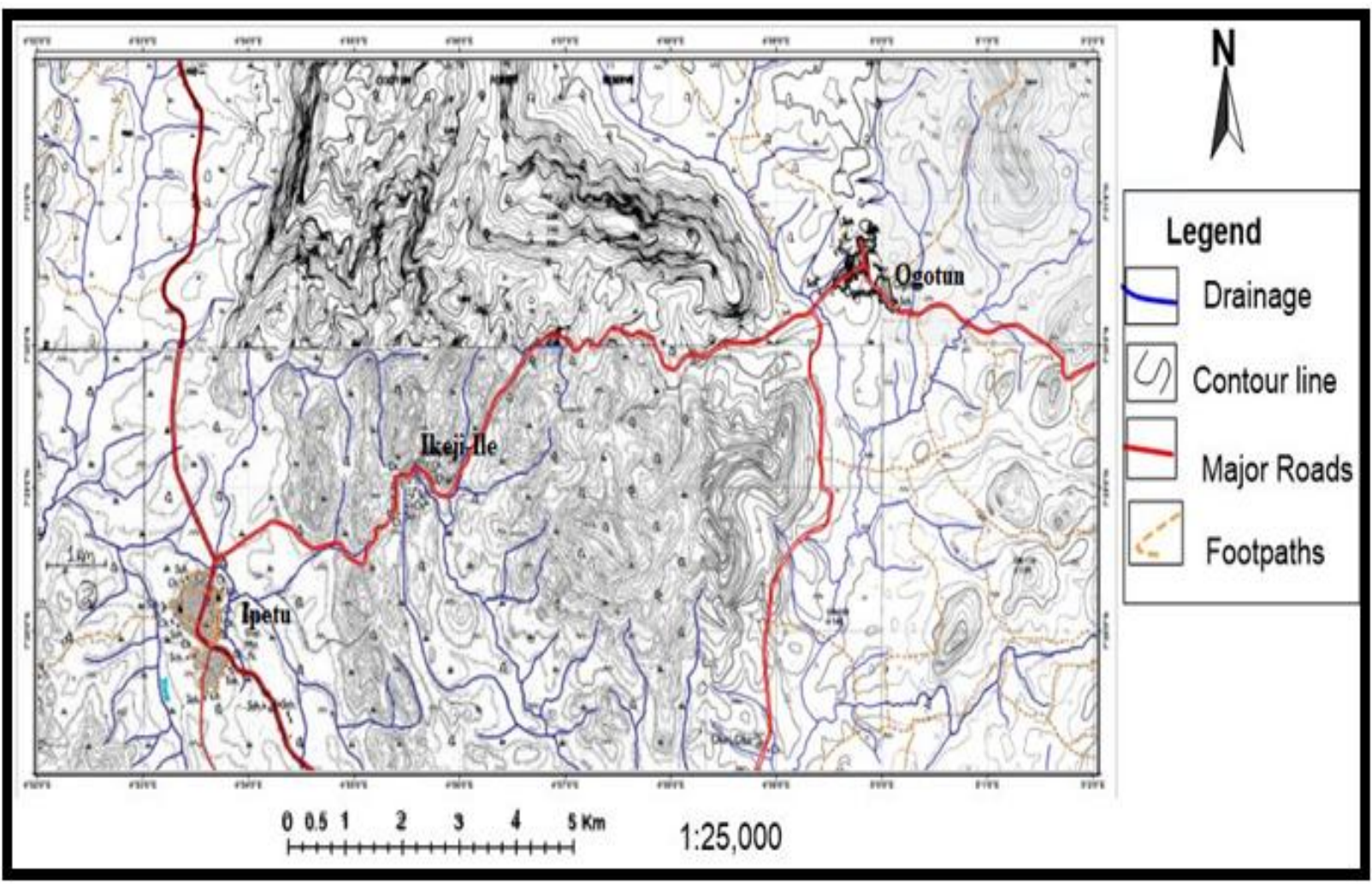

Figure 4. Topographic Map of the study area (Adapted from Topographic sheet 243 and 244, Nigeria Geological Survey Agency (1963)).

The study area lies within latitudes $07^{\circ} 27^{\prime} \mathrm{N}$ and $07^{\circ} 32^{\prime} \mathrm{N}$ and Longitudes $04^{\circ} 52^{\prime} \mathrm{E}$ and $05^{\circ} 2^{\prime} \mathrm{E}$ respectively, it covers part of Ekiti and Osun States with a total surface area of approximately $170 \mathrm{~km}^{2}$ (Figure 3). Major towns 
include Ogotun in Ekiti State, Ikeji-Ile and Ipetu in Osun State. The study area (Ogotun, Ikeji-Ile and Ipetu) is part of the south-eastern part of Ilesha Schist belt; Five lithologic units were identified which includes Migmatite, granite-gneiss, quartzite, quartz schist and porphyritic granites. The studied area is characterized by high relief especially those places that formed quartzite ridge, quart- schists and intrusion of batholitic granites with the highest ridge point which varies from $200 \mathrm{~m}$ to $350 \mathrm{~m}$ (Figure 4); other areas are characterized by presence of flood plains relative to the hills around the area. Also, there are some locations with moderate relief which is either an outcrop formed hill with the highest point over $98 \mathrm{~m}$.

\section{METHODOLOGY}

The methods adopted for this research include: detailed geological mapping of the rocks, petrological analyses using both transmitting and reflecting light microscopes to view and analyse thin sections for mineralogical composition followed by geochemical analyses for major and trace element composition. Thirty-two (32) fresh rock samples were collected with their geographical coordinates documented in the field notebook using the Global Positioning Systems (GPS). Sequel to this, the rock samples were carefully put in the sample bags for onward transmission to the laboratory for petrographic and geochemical analyses. Sampling was systematic as rock samples were taken uniformly at a sampling density of one sample by $3.25 \mathrm{~km}^{2}$ and at a mapping scale of 1:25,000. A total of Thirty-Two (32) rock samples were collected in the field. Each of the fresh bulk rock samples collected from the field were divided into two set of $\mathbf{A}$ and $\mathbf{B}$ to be prepared for two different types of studies namely Petrographic and geochemical studies respectively. Fifteen (15) rock samples were selected from set (A) for Petrographic studies which involved preparation of thin sections from the selected rocks for its identification under transmitting light Microscope; this was done at the petrology laboratory of the Department of Applied Geology, Federal University of Technology, Akure, using the standard procedures. In addition, samples were selected for polished sectioning to be viewed under the reflecting microscope. Ten (10) samples were prepared for geochemical analyses for their major and trace elemental compositions. Sample preparation of the selected rock samples include, crushing, splitting and powdering. These processes homogenize the rock samples and facilitate their decomposition. The pulverized samples were then placed into sample bag and labelled accordingly. The pulverized samples were subjected to geochemical analysis to determine the major and trace elemental composition of the rocks. This was carried out using the Inductively- coupled plasma mass spectrometry (ICP-MS) method at the ACME Laboratories East Vancouver Canada. Meanwhile, Partial digestion method using Lithium Metaborate was used prior to sample decomposition. The resulting geochemical data was then subjected to interpretation and statistical evaluation using relevant software packages such as Excel, Rockworks, (SPSS) etc.

\section{RESULTS AND DISCUSSION}

\subsection{Field Description}

The geological map and cross section of the study area is presented in Figure 5. The map shows the dispositions of the rocks with well delineated boundaries. The cross-section confirmed folding in the study area which affected the quartzites and quartz-schists. The type of fold recognized is an antiform. Fifteen rock samples were collected from various locations within the study area Table 1.

\subsubsection{Migmatitic-Gneiss Complex}

This presumably is the oldest group of rocks and most widely spread; occupying about $60 \%$ of the study area and dominates the eastern part of the study area, especially Ogotun town and its environs. It appears as low-laying outcrops in some areas while it formed an isolated high pluton at Ipetu and practically absence at Ikeji-Ile. The rock is a mixed rock with the characteristics nature of a typical metamorphic rock which has taken an igneous character through partial melting. They resulted from tectonic activities arising from injection of igneous material into pre- 
existing rock and they are high grade metamorphic rock. Migmatite-gneiss complex formed undifferentiated outcrops in the study area based on the mode of formation. The rock is fine -to medium- to coarse grained; the gneissic part of the migmatite is characterized by conspicuous gneissic banding of mafic and felsic minerals of varying thickness while some portion of the migmatite (the granitic part) have a porphyritic texture with a fine matrix of biotite and plagioclase. The most common structural features of this rock are lineation, foliation, dykes, pegmatitic intrusion, joints, cross joints, fractures, xenoliths and cavity hole. The mafic mineral are dominated by biotite, hornblende and opaque minerals while the felsic mineral are mainly quartz and feldspar minerals.

Table 1. Field data.

\begin{tabular}{|c|c|c|c|c|c|c|}
\hline $\begin{array}{l}\text { Sample } \\
\text { ID }\end{array}$ & Location & Latitude & Longitude & Rock type & Structures & Remarks \\
\hline 1 & Ori-oke Ogotun & $07^{0} 30.05^{\prime} \mathrm{N}$ & $04^{\circ} 58.751^{\prime} \mathrm{E}$ & $\begin{array}{l}\text { Migmatite } \\
\text { Gneiss }\end{array}$ & $\begin{array}{l}\text { Exfoliation, differential } \\
\text { weathering }\end{array}$ & \\
\hline 2 & $\begin{array}{l}\text { Okemi (Pa Tunji } \\
\text { comp. Ogotun }\end{array}$ & $07^{0} 30.453^{\prime} \mathrm{N}$ & $05^{\circ} 00.062^{\prime} \mathrm{E}$ & $\begin{array}{l}\text { Migmatite } \\
\text { Gneiss }\end{array}$ & Fracture, dykes and vein & \\
\hline 3 & $\begin{array}{l}\text { Off Igbara Odo } \\
\text { Road Ogotun }\end{array}$ & $07^{0} 30.571^{\prime} \mathrm{N}$ & $05^{\circ} 00.127^{\prime} \mathrm{E}$ & $\begin{array}{l}\text { Migmatite } \\
\text { Gneiss }\end{array}$ & Solution hole exfoliation & \\
\hline 4 & Okemi (1) Ogotun & $07^{\circ} 30.598^{\prime} \mathrm{N}$ & $05^{\circ} 00.76^{\prime} \mathrm{E}$ & $\begin{array}{l}\text { Migmatite } \\
\text { Gneiss }\end{array}$ & $\begin{array}{l}\text { Xenoliths, boulders, } \\
\text { pegmatite intrusion }\end{array}$ & \\
\hline 5 & $\begin{array}{l}\text { Okemi }(2), \\
\text { Ogotun }\end{array}$ & $07^{\circ} 29.569^{\prime} \mathrm{N}$ & $05^{\circ} \mathrm{O} 1.039^{\prime} \mathrm{E}$ & $\begin{array}{l}\text { Migmatite } \\
\text { Gneiss }\end{array}$ & $\begin{array}{l}\text { Dykes, folds solution } \\
\text { hole }\end{array}$ & \\
\hline 6 & $\begin{array}{l}\text { Otapete, } \\
\text { Ogotun }\end{array}$ & $07^{\circ} 28.863^{\prime} \mathrm{N}$ & $05^{\circ} 00.876^{\prime} \mathrm{E}$ & $\begin{array}{l}\text { Migmatite } \\
\text { Gneiss }\end{array}$ & $\begin{array}{l}\text { Solution hole, pegmatite } \\
\text { intrusion }\end{array}$ & \\
\hline 7 & $\begin{array}{l}\text { St Jude's ANG. } \\
\text { Church, Ikeji-Ile }\end{array}$ & $07^{\circ} 28.97^{\prime} \mathrm{N}$ & $04^{\circ} 55.565^{\prime} \mathrm{E}$ & $\begin{array}{l}\text { Quartz } \\
\text { Schist }\end{array}$ & Joints and quartz vein & $\begin{array}{l}\text { Strike } \\
30^{\circ} \mathrm{SE} \\
\text { Dip } 80^{\circ} \mathrm{W}\end{array}$ \\
\hline 8 & $\begin{array}{l}\text { Beside ,Sericoco } \\
\text { Hotel ,Ipetu }\end{array}$ & $07^{\circ} 27.213 \mathrm{~N}$ & $04^{\circ} 54.051 \mathrm{E}$ & $\begin{array}{l}\text { Porphyritic } \\
\text { Granite }\end{array}$ & $\begin{array}{l}\text { Fractures, Jonts and } \\
\text { micro faults }\end{array}$ & \\
\hline 9 & $\begin{array}{l}\text { Kristal V.LTD } \\
\text { Quarry Ipetu }\end{array}$ & $07^{0} 29.569^{\prime} \mathrm{N}$ & $04^{\circ} 53.891^{\prime} \mathrm{N}$ & $\begin{array}{l}\text { Porphyritic } \\
\text { Granite }\end{array}$ & Pegmatite intrusion & \\
\hline 10 & Araromi ,Iptetu & $07^{\circ} 28.495^{\prime} \mathrm{N}$ & $04^{\circ} 53.577^{\prime} \mathrm{E}$ & $\begin{array}{l}\text { Metaconglo } \\
\text { merate }\end{array}$ & Crenulations, xenolith & \\
\hline 11 & $\begin{array}{l}\text { Under power line } \\
\text { along Ikeji-Ile } \\
\text { road }\end{array}$ & $07^{\circ} 28.913^{\prime} \mathrm{N}$ & $04^{\circ} 54.454^{\prime} \mathrm{E}$ & $\begin{array}{l}\text { Migmatite } \\
\text { Gneiss }\end{array}$ & Xenolith, solution hole & \\
\hline 12 & Oke Ayile Ikeji-Ile & $07^{\circ} 30.047^{\prime} \mathrm{N}$ & $04^{\circ} 55.780^{\prime} \mathrm{E}$ & $\begin{array}{l}\text { Porphyritic } \\
\text { Granite }\end{array}$ & Xenolith, joints & \\
\hline 13 & Oke arifo,Ikeji-Ile & $07^{\circ} 30.223^{\prime} \mathrm{N}$ & $04^{\circ} 55.689^{\prime} \mathrm{E}$ & $\begin{array}{l}\text { Porphyritic } \\
\text { Granite }\end{array}$ & $\begin{array}{l}\text { Pegmatitic Intrusion, } \\
\text { Xenolith and solution } \\
\text { cavity }\end{array}$ & \\
\hline 14 & $\begin{array}{l}\text { Off Ikeji-Ile road } \\
\text {,Ipetu }\end{array}$ & $07^{\circ} 29.317^{\prime} \mathrm{N}$ & $04^{\circ} 56.006^{\prime} \mathrm{E}$ & Quartzite & $\begin{array}{l}\text { Schistosity of the } \\
\text { quartzite. }\end{array}$ & $\begin{array}{l}\text { Strike } \\
42^{\circ} \mathrm{SW}\end{array}$ \\
\hline 15 & $\begin{array}{l}\text { Off Ilesha road } \\
\text { Ipetu }\end{array}$ & $07^{030.037^{\prime} \mathrm{N}}$ & $04^{\circ} 53.827^{\prime} \mathrm{E}$ & $\begin{array}{l}\text { Quartz } \\
\text { Schist }\end{array}$ & $\begin{array}{l}\text { Fine to medium grain } \\
\text { and presence of flaky } \\
\text { minerals such as } \\
\text { muscovite, biotite }\end{array}$ & $\begin{array}{l}\text { Strike } \\
18^{\circ} \mathrm{NE} \\
\text { Dip } 58^{\circ} \mathrm{W}\end{array}$ \\
\hline
\end{tabular}

\subsubsection{Quartzite/Quartz-Schist}

These tend to form good topographical features which rise up to about 350meters above the surrounding terrains forming ridges. These outcrops dominated the central to western part of the study area which covered Ikeji-Ile and Ipetu area but conspicuously absent at the eastern part of the study area particularly Ogotun area. Ikeji-Ile is dominated by high relief, massive and schistose quartzites which formed long and extensive ridges. The schistose quartzites are foliated with clear exhibition of alternating felsic and mafic minerals. The mafic mineral is mostly biotite with planar fabric while the felsic mineral is quartz. Quartz-schist is form by medium grade metamorphism of semi-pelitic rocks. At Oke Arifo in Ikeji-Ile where there is massive and extensive schistose quartzite, hydrothermal alteration was observed (Figure 6a) to form the pegmatitic dykes' intrusion that was mapped on the schistose quartzite. Weathering had impacted negatively on some of the schistose quartzites at IkejiIle, this manifested different sizes of solution cavities resulted from differential weathering on the outcrops. 
Structural features such as joints, multiple joints and folds were also identified on the schistose quartzite, which are evidences of the level of deformation; at Ipetu this deformed quartzite was found to host chalcopyrite. The massive quartzite are exhibits granular texture and are friable when struck with hammer. It is hard, non-foliated metamorphic rock, it formed a sharp boundary with the migmatite gneiss at Ogotun while heading toward Ikeji-Ile. The strong interlocking crystalline structure of quartzite makes it hard, tough and durable rock (locally) that affected the study area. Also in quartz schist, quartz, biotite and opaque minerals are found both as granular finemedium grained regions, with a grain-flattening and as lenticular polycrystalline bodies up to $3 \mathrm{~mm}$ in width although the quartz-schist had been weathered with multiple joints. The opaque minerals formed part of the mineral compositions of quartz schist in Ikeji-Ile Figure $6 \mathrm{~b}$.

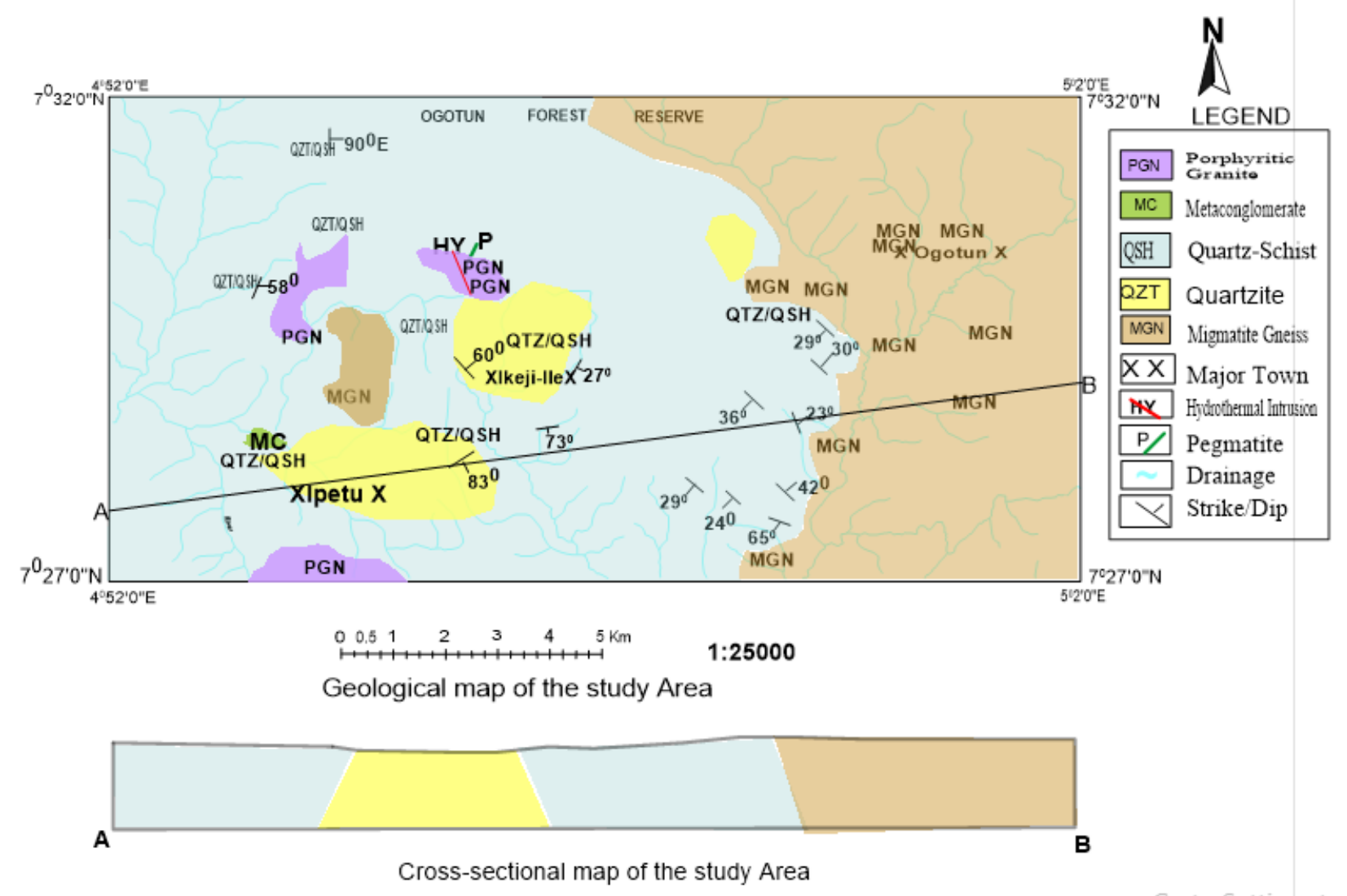

Figure 5. (a) Geological map and (b) cross-section of the study Area.

\subsubsection{Metaconglomerate}

This was observed as an isolated, moderately high outcrop only in one location at Ipetu, southwestern part of the study area. The out crop is located very close to a river channel in the town and it is easily identifiable by its pebbly and cobbly clast set in a fine grains matrix. Metaconglomerate is a coarse -grained rock containing rounded to sub-angular fragments and distributed in a fine-grained matrix (Figure 6c). The clasts show physical stretching which is an evidence of deformation on the outcrop. The common structural features on the outcrop are foliation, crenulation, joints and multiple joints. The metaconglomerate is clast supported, quartz and granites are the observed clast that formed the polymixed metaconglomerate. The common minerals present in the outcrop are quartz, feldspar, biotite, microcline and opaque minerals

\subsubsection{Porphyritic Granite}

It occurred as an intrusion in the study area. In most locations, it occurred as a high rising pluton, low lying flat and extensive with sparse vegetation. The occurrence are prominent at Ipetu the western part of the study area, it also formed an isolated outcrop at Ikeji-Ile where it intruded the quartzite. Structure common to the outcrop 
include quartz vein, veinlet, pegmatite, dykes, exfoliation, xenoliths etc. Weathering of the granites are intense and the degree of weathering varies from moderate to severe at different locations. In some places fractures were identified in the granites (Figure 6d) along which physical weathering was believed to have taken place, which led to the peeling and breaking off parts of the rock in concentric layers thus resulting in "rounding". Boulders and pebbles were also identified. Porphyritic granite has a composition of mafic and felsic minerals, the mafic minerals are biotite and hornblende while the felsic minerals are quartz, microcline and plagioclase feldspar. The mineral grains were identified to interlock one another which are texturally coarse to porphyritic. This textural quality is to the advantage of its quarry for various construction purposes.
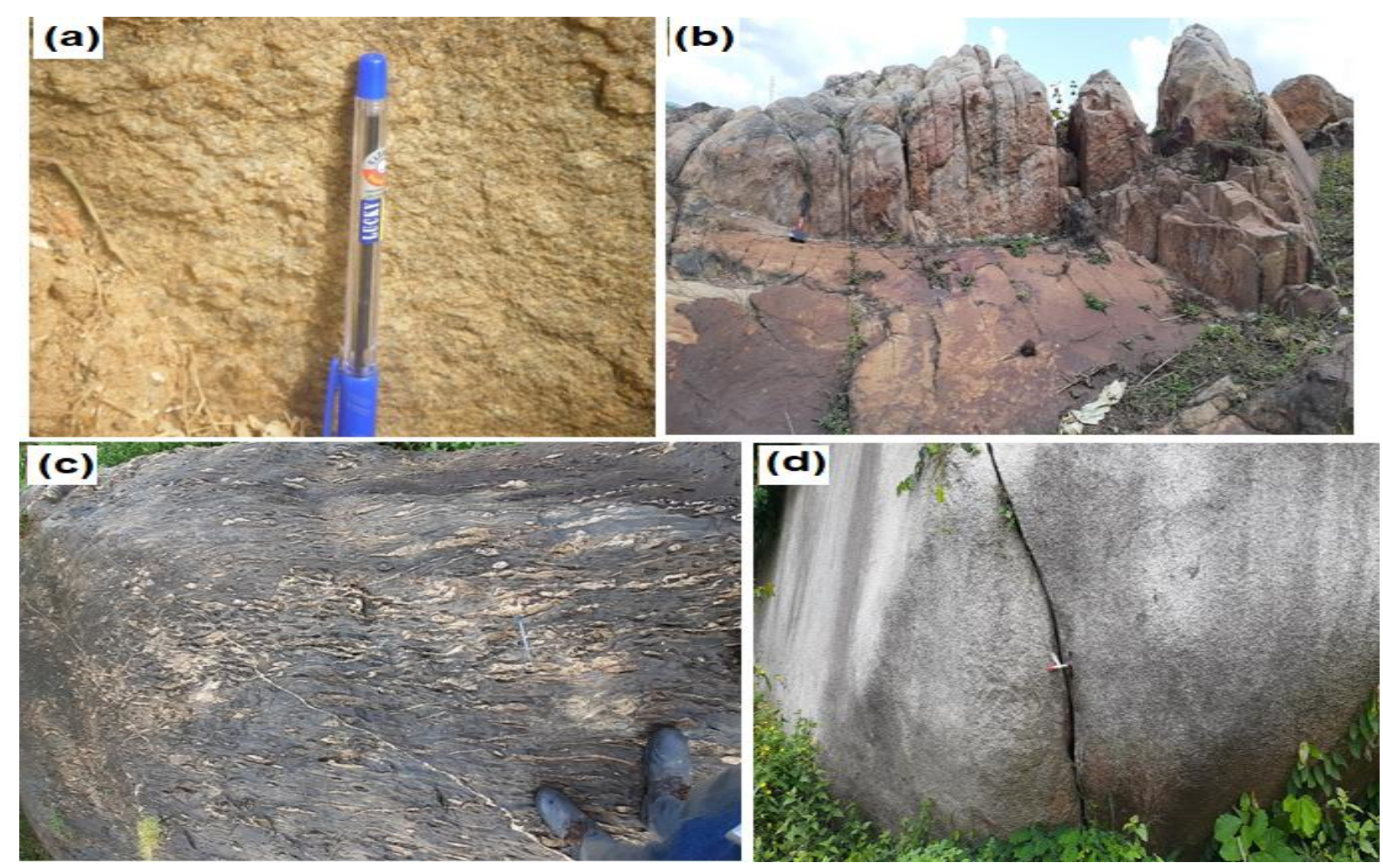

Figure 6. (a) alteration surface at Ikeji-Ile, (b) the quartz-schist at Ikeji-Ile, (c) metaconglomerate at Araromi- Ipetu and (d) porphyritic granite displaying deep fracture at Ipetu.

\subsection{Optical Properties of the Minerals in the Rocks 5.2.1. Migmatite-Gneisses}

The rockslide observed under transmitting light microscope revealed the presence of minerals such as biotite, plagioclase, quartz, microcline, opaque and orthoclase (Figures $7 \mathrm{a}$ and b; $8 \mathrm{a}$ and b). Biotite occur as platy, high relief and strongly pleochronic brownish crystals with pleochronic colour range from dark brown to light green and with cleavage in one direction. Closely associated with biotite are opaque minerals. Plagioclase occur in a small lath crystals engulfing the quartz with well defined lamella of repeated albite twinning. Microcline appear as low relief, small lath crystals and is characteristic of multiple twinning (cross -hatched). Orthoclase distinguishing factor from other feldspar is the Carlsbad twinning. Quartz occur as subhedral to anhedral low relief crystals with waxy extinction and occur mostly at the edge of the section.

\subsubsection{Quartzite/Quartz Schist}

The observation of the thin section under the polarizing microscope revealed the presence of minerals such as biotite, plagioclase, microcline, Myrmekite, quartz and opaque minerals (Figure 7c and 8c). Biotite occur as platy, high relief and strongly pleochronic brownish crystals with pleochronic colour range from dark brown to light 
green with cleavage in one direction. Closely associated with biotite are opaque mineral. Plagioclase occur in a small and large lath crystals engulfing the quartz with well defined lamella of repeated albite twinning. Microcline appear as low relief, small lath crystals and is characteristic of multiple twinning (cross -hatched). Also some of the microcline could have been converted to plagioclase. Quartz is the most dominant mineral and of various sizes mostly anhedral and occur mostly at the edge of the section.
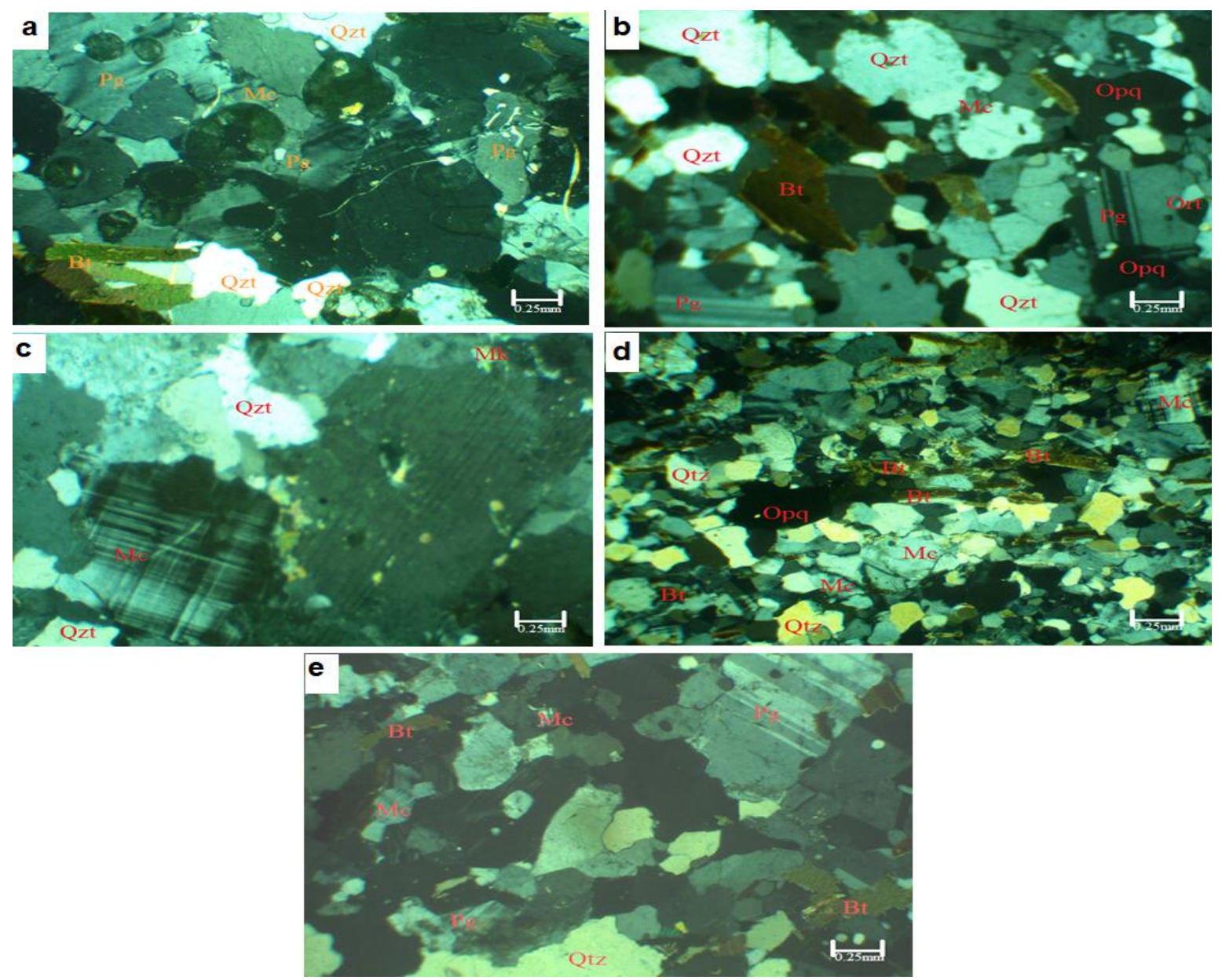

Figure 7. (a) Photomicrograph of migmatite gneiss along Okemi (2) Ogotun, (b) migmatite gneiss along Ikeji-Ile Ipetu, (c) schistose quartzite off Ikeji-Ile Road, Ipetu, (d) Metaconglomerate at Araromi Ipetu and (e) Sericoco Hotel, Ipetu under crossed nicol (Cn) showing Quartz (Qtz). Biotite (Bt), Orthoclase (Ort), microcline (Mc), Opaque $(\mathrm{Oq})$ and plagioclase $(\mathrm{Pg})$.

\subsubsection{Metaconglomerate}

The minerals identified under the thin section include biotite, plagioclase, microcline, quartz and opaque mineral (Figure $7 \mathrm{~d}$ and $8 \mathrm{~d}$ ). Biotite occur as platy, high relief and strongly pleochronic brownish crystals with pleochronic colour range from dark brown to light green with cleavage in one direction. Closely associated with biotite are opaque mineral. Plagioclase occur as subhedral prismatic low relief grains. It is distinctive of its repeated albite twinning with fairly develop lamella. Microcline appear as low relief, small lath crystals and is characteristic of multiple twinning (cross -hatched). Quartz is the most dominant mineral and of various sizes ranging from subhedral to anhedral, low relief crystals with waxy extinction and occur mostly at the edge of the section.

\subsubsection{Porphyritic Granite}

The observation under the microscope revealed the presence of minerals such as biotite, plagioclase, K-feldspar, quartz and orthoclase (Figure 7e and 8e). Quartz occur as anhedral crystal with low relief and has parallel extinction in longitudinal section. Biotite occur as platy elongated high relief greenish brown subhedral crystals which is strongly pleochronic with perfect cleavage in one direction. Plagioclase occur as subhedral prismatic low 
relief grains. K-feldspar occur in trace amount as subhedral small lath crystals with low relief and very low extinction angle interference colour.

\subsubsection{Polished Section}

Five rock samples were prepared for polished sections which were analysed using the reflected Ore Microscope, Three out of the five sections were discovered to have a Metallic mineral which has brassy yellow colour as one of its optical properties to be confirmed as Chalcopyrite. However, this brassy yellow metallic mineral (Figure 9) is obvious and more pronounce in the polish section of quartz- schist rock's sample of Ikeji-Ile as showing in the photomicrograph.

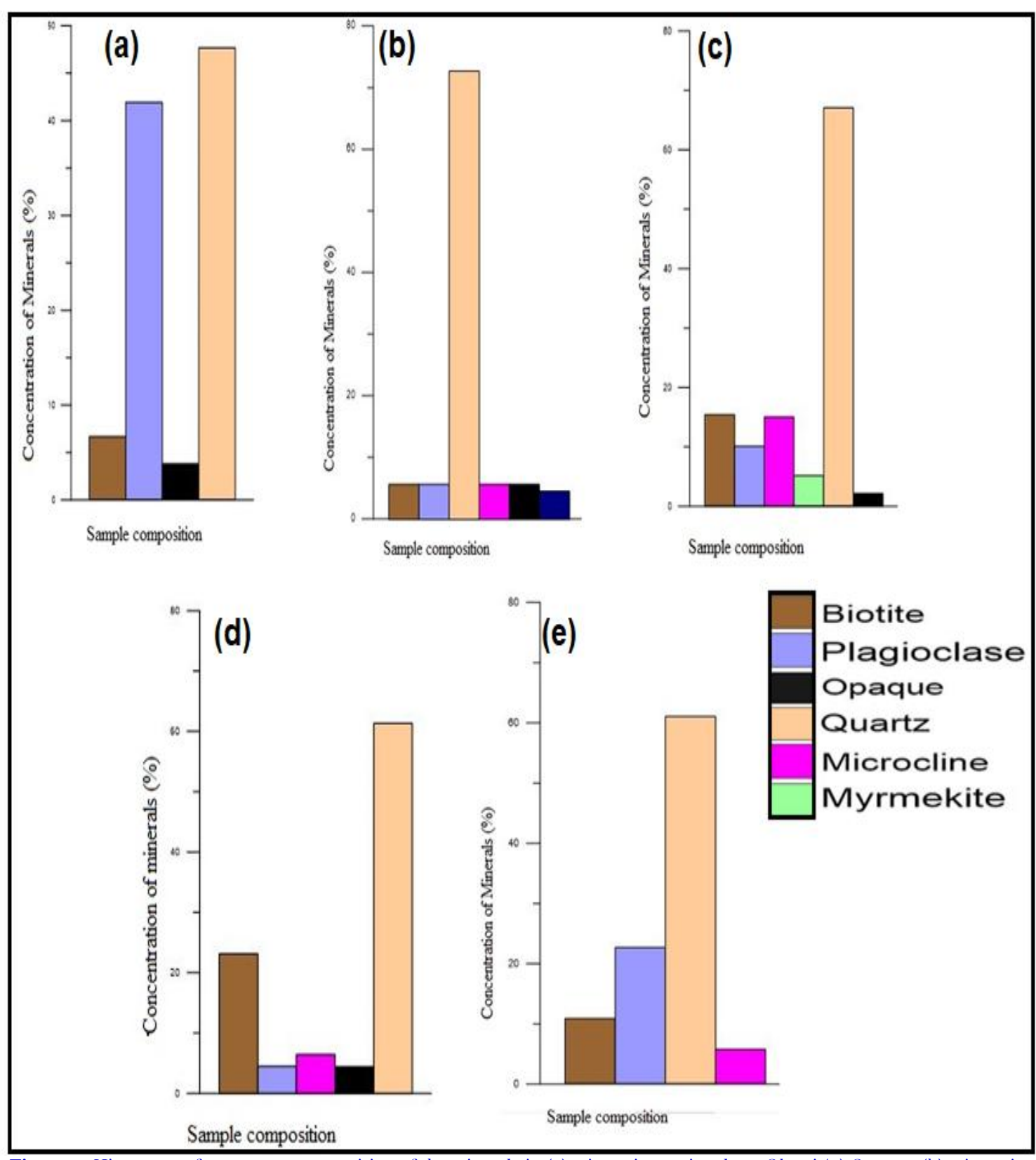

Figure 8. Histogram of percentage composition of the minerals in (a) migmatite gneiss along Okemi (2) Ogotun, (b) migmatite gneiss along Ikeji-Ile Ipetu, (c) schistose quartzite off Ikeji-Ile Road, Ipetu, (d) Metaconglomerate at Araromi Ipetu and (e) Sericoco Hotel, Ipetu 


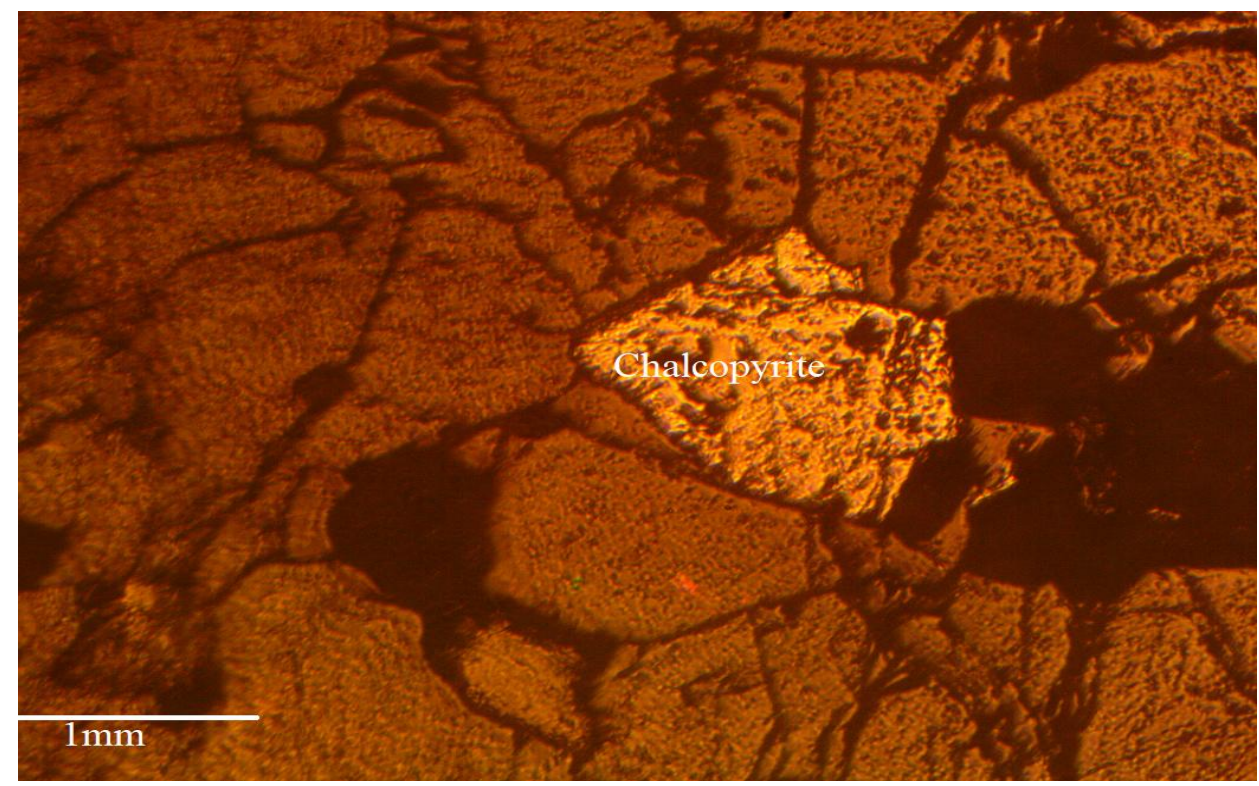

Figure 9. Photomicrograph of Chalcopyrite in a polished section of Quartz schist at Ikeji-Ile.

\subsection{Geochemistry}

\subsubsection{Major Oxide Geochemistry}

The major oxides analysed in the rock samples are $\mathrm{SiO}_{2}, \mathrm{Al}_{2} \mathrm{O}_{3}, \mathrm{Fe}_{2} \mathrm{O}_{3}, \mathrm{MgO}, \mathrm{CaO}, \mathrm{Na}_{2} \mathrm{O}, \mathrm{K}_{2} \mathrm{O}, \mathrm{TiO}_{2}, \mathrm{P}_{2} \mathrm{O}_{5}$, $\mathrm{MnO}$ and $\mathrm{Cr}_{2} \mathrm{O}_{3}$. The geochemical results (Table 2) shows the following ranges: $\mathrm{SiO}_{2}(67.37 \%-62.46 \%), \mathrm{Al}_{2} \mathrm{O}_{3}($ $17.35 \%-11.62 \%$ ), $\mathrm{Fe}_{2} \mathrm{O}_{3}$ (total) (6.44\%-2.3\%), $\mathrm{MgO}$ (3.18\%-1.02\%), $\mathrm{CaO}$ (5.04\%- 0.72\%), $\mathrm{Na}_{2} \mathrm{O}(4.1 \%-2.44), \mathrm{K}_{2} \mathrm{O}($ $6.95 \%-2.01 \%), \mathrm{TiO}_{2}$ ( $\left.0.96 \%-0.21 \%\right), \mathrm{P}_{2} \mathrm{O}_{5}$ (10.02- 0.25\%), $\mathrm{MnO}(0.17 \%-0.07 \%)$ and $\mathrm{Cr}_{2} \mathrm{O}_{3}(<0.002-0.012 \%)$. The result revealed that the rocks in the studied area are rich in silica, moderately rich in feldspars (Plagioclase, sodic and potassic), feldspathoids as well as being aluminosilicate in nature while other oxides such as $\mathrm{CaO}_{2} \mathrm{Na}_{2} \mathrm{O} \mathrm{P}_{2} \mathrm{O}_{5}$ and $\mathrm{TiO}_{5}$ are present in minor to trace amounts in the rocks .Major oxides are regarded to as lithological index that reflects the geology of underlying rocks (Ojo, 1988).

Table 2. Major Oxide geochemistry (wt) \%.

\begin{tabular}{c|c|c|c|c|c|c|c|c|c|c}
\hline $\begin{array}{c}\text { Major } \\
\text { Oxide }\end{array}$ & LOC 1 & LOC 2 & LOC 3 & LOC 4 & LOC 5 & LOC 6 & LOC 7 & LOC 8 & LOC 9 & LOC 10 \\
\hline $\mathrm{SiO}_{2}$ & 63.76 & 62.46 & 67.37 & 66.02 & 65.03 & 63.26 & 63.6 & 62.66 & 66.28 & 66.6 \\
\hline $\mathrm{Al}_{2} \mathrm{O}_{3}$ & 15.57 & 17.04 & 11.62 & 12.7 & 15.74 & 17.35 & 16.59 & 15.77 & 15.15 & 15.74 \\
\hline $\mathrm{Fe}_{2} \mathrm{O}_{3}$ & 6.44 & 6.4 & 2.3 & 2.78 & 3.15 & 5.8 & 5.62 & 5.07 & 3.38 & 4.7 \\
\hline $\mathrm{MgO}$ & 1.02 & 2.88 & 3.04 & 3.18 & 3.3 & 1.31 & 2.3 & 2.71 & 1.85 & 1.35 \\
\hline $\mathrm{CaO}$ & 0.72 & 0.95 & 4.91 & 3.98 & 5.04 & 2.82 & 3.63 & 3.33 & 4.73 & 3.63 \\
\hline $\mathrm{Na}_{2} \mathrm{O}$ & 3.76 & 3.68 & 3.5 & 3.33 & 4.1 & 3.99 & 2.82 & 2.44 & 3.51 & 4.1 \\
\hline $\mathrm{K}_{2} \mathrm{O}$ & 6.95 & 5.01 & 4.65 & 4.88 & 2.01 & 3.33 & 3.05 & 5.11 & 2.87 & 2.43 \\
\hline $\mathrm{TiO}_{2}$ & 0.21 & 0.28 & 0.93 & 0.96 & 0.69 & 0.59 & 0.41 & 0.59 & 0.49 & 0.67 \\
\hline $\mathrm{P}_{2} \mathrm{O}_{5}$ & 0.03 & 0.02 & 0.03 & 0.16 & 0.19 & 0.21 & 0.25 & 0.22 & 0.12 & 0.18 \\
\hline $\mathrm{MnO}^{\mathrm{Cr}} \mathrm{O}_{3}$ & 0.09 & 0.11 & 0.09 & 0.09 & 0.07 & 0.08 & 0.12 & 0.14 & 0.13 & 0.17 \\
\hline $\mathrm{LOI}$ & 1.3 & 1.1 & 1.4 & 1.8 & 0.6 & 1.1 & 1.5 & 1.9 & 1.4 & 1.3 \\
\hline $\mathrm{Sum}$ & 99.85 & 99.95 & 99.75 & 99.88 & 99.92 & 99.87 & 99.89 & 99.94 & 99.93 & 99.89 \\
\hline
\end{tabular}

The Harker plots for $\mathrm{SiO}_{2}$ against different oxides is presented in Figure 10. The scattering of the samples in all the plots suggest that there is no proportionality either directly or indirectly between the $\mathrm{SiO}_{2}$ with any of the oxides in the study area. The plots showed that $\mathrm{SiO}_{2}$ does not correlate with any of the oxides in term of percentage composition. This may suggest that the rock in the study area are not from the same parent rock and they are not derived from the similar source materials. 

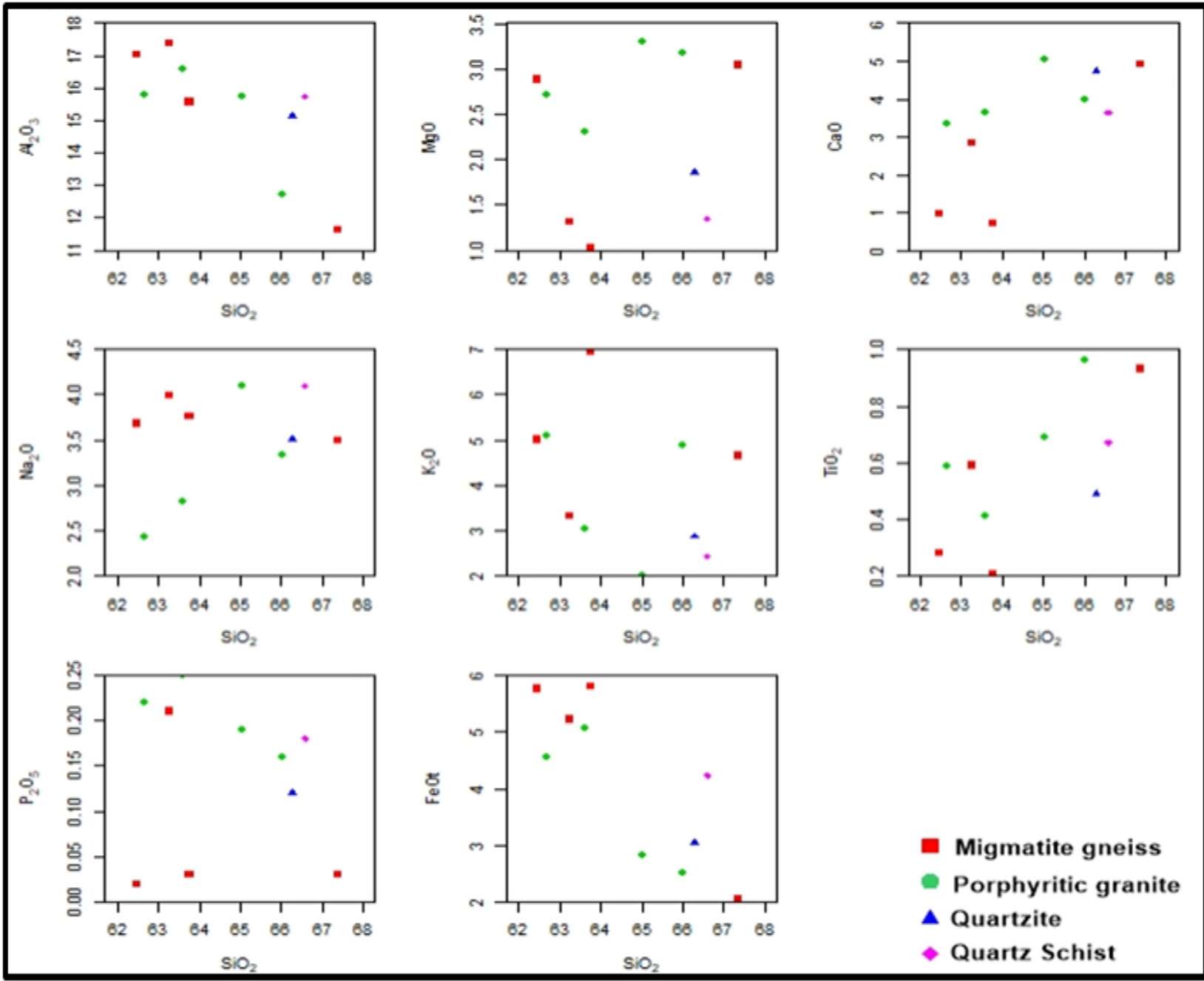

Figure 10. Harker plots of $\mathrm{SiO}_{2}$ vs. other oxides (wt \%).

\subsubsection{Trace Elements Geochemistry}

Trace element composition is useful in finger printing the origin of rocks and preceding processes because they exhibit a wide range in concentration and mineralization potential of a particular setting more than major element (Frost, Frost, Chamberlain, \& Edwards, 1999). The results of trace element analysis is presented in Table 3. The analyses revealed that $\mathrm{Ba}, \mathrm{Cu}, \mathrm{Pb}, \mathrm{Sr}, \mathrm{Zr}, \mathrm{Cr}, \mathrm{Mn}, \mathrm{Fe} \mathrm{Zn}, \mathrm{Co}, \mathrm{Rb}$ and $\mathrm{Li}$ have high concentrations in the migmatitegneisses, quartzite, quartz-schist and porphyritic granite of the study area. The concentration ranges as follows: Ba (2533-10) ppm, Cu (38.4-12.5) ppm, Pb (39.4-0.9) ppm, Zn (156-7) ppm, Co (65.2-1.4) ppm, Rb (311.6-0.5) ppm, Sr (839-145) ppm, Cr (1310-5) ppm, Fe (55000-4100) ppm, Zr (743-220) ppm and Li (59.1-1.4) ppm respectively. Ba, $\mathrm{Cr}, \mathrm{Cu}, \mathrm{Mn}$ and $\mathrm{Zn}$ have diagnostic value with respect to other element and their value related to bedrock geology which suggests the absence of basic and ultrabasic source materials for the rocks in the area. For instance, Ba, Sr, $\mathrm{Mn}, \mathrm{Rb}, \mathrm{Cu}, \mathrm{Zn}, \mathrm{Mn}, \mathrm{Pb}$ and $\mathrm{Fe}$ have higher concentration in the migmatite-gneisses at Pa Olatunji Compound and Otapete farm in Ogotun Ekiti which is also recorded at migmatite gneiss, porphyritic granite, quartzite and quartz schist in Ipetu; this underscore the nature of the underlain bedrock in Ipetu suggesting the absence of basic and ultrabasic source materials. Th and $\mathrm{U}$ have their highest concentration also at Ipetu particularly on the porphyritic granite at Kristal V. Quarry revealing the radioactive potentials of the porphyritic granite in that location. Meanwhile, the porphyritic granite at Oke Arifo in Ikeji-Ile recorded higher concentration of $\mathrm{Sr}, \mathrm{Zr}, \mathrm{Cu}, \mathrm{Zn}$, $\mathrm{Co}, \mathrm{Mn}, \mathrm{Fe}$ and highest concentration of $\mathrm{Cr}$ and $\mathrm{Mg}$ in the study area; these indicate that the bedrocks are of magnesium and chromium bearing granitic materials. Y, Nb, Sc, Mo show very little concentration in the rocks of the study area. $\mathrm{Cu}, \mathrm{Pb}, \mathrm{Zn}, \mathrm{Ag}$ and $\mathrm{Co}$ show moderate concentration. Meanwhile, Mn, Fe, show very high 
concentration indicating the tropical nature of the environment of deposition, while $\mathrm{Fe}$ arose from the weathering of the silicate-bearing rocks in the area. The value of $\mathrm{Au}$ is very low but its pathfinder element $\mathrm{As}, \mathrm{Cu}, \mathrm{Zn}$ and $\mathrm{Pb}$ show very promising concentrations in the quartz-schists and the migmatite-gneisses. $\mathrm{Ni}, \mathrm{Nb}, \mathrm{Sn}, \mathrm{Ta}$ concentrations are moderate to very low in the migmatites, quartzites and quartz-schists but very low in the granites which are indicative of felsic bedrock lithology.

Table 3. Trace elements composition (ppm).

\begin{tabular}{|c|c|c|c|c|c|c|c|c|c|c|}
\hline Elements & LOC 1 & LOC 2 & LOC 3 & LOC 4 & LOC 5 & LOC 6 & LOC 7 & LOC 8 & LOC 9 & LOC 10 \\
\hline $\mathrm{Ba}$ & 76 & 80 & 73 & 67 & 83 & 89 & 78 & 67 & 472 & 377 \\
\hline $\mathrm{Ni}$ & 20 & 50 & 108 & 85 & 56 & 24 & 20 & 27 & 59 & 62 \\
\hline $\mathrm{Sr}$ & 145 & 182 & 483 & 449 & 437 & 386 & 263 & 382 & 761 & 839 \\
\hline $\mathrm{Zr}$ & 220 & 231 & 326 & 555 & 360 & 743 & 475 & 284 & 385 & 294 \\
\hline $\mathrm{Y}$ & 3 & 6 & 30 & 45 & 39 & 60 & 51 & 30 & 29 & 27 \\
\hline $\mathrm{Nb}$ & 19 & 15 & 16 & 23 & 24 & 28 & 27 & 14 & 15 & 22 \\
\hline $\mathrm{Sc}$ & $<1$ & $<1$ & $<1$ & 1 & 3 & 12 & 4 & 4 & 20 & 20 \\
\hline Mo & 0.4 & 1.4 & 0.7 & 1.2 & 2.4 & 1.1 & 0.9 & 0.1 & 0.5 & 1.4 \\
\hline $\mathrm{Cu}$ & 15.9 & 15.3 & 38.4 & 19.5 & 22.3 & 22.5 & 12.5 & 16.2 & 37.1 & 35.3 \\
\hline $\mathrm{Pb}$ & 23.6 & 1.4 & 24.7 & 31.1 & 23.3 & 28.2 & 39.4 & 0.9 & 17.5 & 21.4 \\
\hline $\mathrm{Zn}$ & 7 & 17 & 72 & 156 & 69 & 125 & 72 & 75 & 84 & 77 \\
\hline $\mathrm{Ag}$ & $<0.1$ & $<0.1$ & $<0.1$ & $<0.1$ & $<0.1$ & $<0.1$ & $<0.1$ & $<0.1$ & $<0.1$ & $<0.1$ \\
\hline $\mathrm{Ni}$ & 1.9 & 17.4 & 27.3 & 2 & 8.5 & 1.9 & 2.1 & 37.4 & 65.5 & 87.4 \\
\hline $\mathrm{Co}$ & 22.3 & 14.8 & 18.3 & 3.1 & 11.1 & 4.4 & 1.4 & 65.2 & 31.4 & 44.8 \\
\hline As & 2 & 1 & 1 & 1 & 3 & 2 & 2 & 2 & 2 & 1 \\
\hline $\mathrm{U}$ & 2.6 & $<0.1$ & 0.7 & 0.8 & 6.3 & 1.2 & 3.7 & 1.1 & 0.7 & 0.9 \\
\hline $\mathrm{Au}$ & $<0.1$ & $<0.1$ & $<0.1$ & $<0.1$ & $<0.1$ & $<0.1$ & $<0.1$ & $<0.1$ & $<0.1$ & $<0.1$ \\
\hline Th & 1.5 & 0.2 & 7.1 & 11.8 & 30.5 & 12.3 & 50.1 & $<0.1$ & 3.5 & 4.2 \\
\hline $\mathrm{Sr}$ & 139 & 31 & 706 & 249 & 447 & 388 & 58 & 2 & 824 & 831 \\
\hline $\mathrm{Cd}$ & $<0.1$ & $<0.1$ & $<0.1$ & 0.2 & $<0.1$ & 0.1 & 0.1 & $<0.1$ & $<0.1$ & $<0.1$ \\
\hline $\mathrm{Sc}$ & 0.1 & 0.1 & $<0.1$ & $<0.1$ & 0.1 & $<0.1$ & $<0.1$ & 0.2 & 0.1 & 0.1 \\
\hline $\mathrm{Bi}$ & $<0.1$ & $<0.1$ & $<0.1$ & $<0.1$ & 0.1 & $<0.1$ & $<0.1$ & $<0.1$ & $<0.1$ & $<0.1$ \\
\hline $\mathrm{V}$ & $<1$ & 22 & 107 & 4 & 75 & 4 & 3 & 31 & 137 & 162 \\
\hline $\mathrm{P}$ & 0.013 & 0.001 & 0.2 .2 & 0.067 & 0.083 & 0.078 & 0.019 & $<0.001$ & 0.174 & 0.181 \\
\hline $\mathrm{Cr}$ & 5 & 12 & 73 & 6 & 11 & 6 & 8 & 1310 & 170 & 212 \\
\hline $\mathrm{Ti}$ & 0.01 & 0.029 & 0.577 & 0.337 & 0.431 & 0.36 & 0.128 & 0.161 & 0.539 & 0.629 \\
\hline $\mathrm{W}$ & 0.5 & $<0.1$ & 0.6 & 0.3 & 0.6 & 0.3 & $<0.1$ & 14.1 & 0.4 & 0.6 \\
\hline $\mathrm{Zr}$ & 20.3 & 0.3 & 16 & 7.2 & 52.4 & 8.5 & 170.2 & 0.6 & 21 & 30 \\
\hline $\mathrm{La}$ & 3 & 0.8 & 404 & 86.8 & 46.4 & 74.5 & 193.7 & 2.4 & 38.3 & 40.8 \\
\hline $\mathrm{Ce}$ & 6 & 1 & 91 & 202 & 95 & 169 & 379 & 6 & 77 & 71 \\
\hline Sn & 2.8 & 0.9 & 1.7 & 1.8 & 2.7 & 2.2 & 1.7 & 0.3 & 1.2 & 1.9 \\
\hline $\mathrm{Y}$ & 4 & 0.2 & 17.4 & 62.4 & 25.7 & 46.7 & 53.6 & 1.1 & 19.1 & 20.2 \\
\hline $\mathrm{Nb}$ & 41.5 & $<0.1$ & 14.6 & 34.9 & 24.5 & 29.3 & 15.7 & 0.4 & 8.9 & 10.01 \\
\hline $\mathrm{Ta}$ & 6.7 & $<0.1$ & 0.8 & 1.5 & 2 & 1.4 & 0.4 & 0.4 & 0.5 & 0.3 \\
\hline $\mathrm{Be}$ & 19 & $<1$ & 3 & 3 & 8 & 3 & 2 & $<1$ & 2 & 2 \\
\hline $\mathrm{Sc}$ & $<1$ & 3 & 12 & 16 & 3 & 9 & 3 & 3 & 19 & 23 \\
\hline $\mathrm{Li}$ & 3 & 8.1 & 20.8 & 29.7 & 89.1 & 13.8 & 18.6 & 1.4 & 20.6 & 28.1 \\
\hline $\mathrm{S}$ & $<0.1$ & $<0.1$ & $<0.1$ & $<0.1$ & $<0.1$ & $<0.1$ & $<0.1$ & $<0.1$ & $<0.1$ & $<0.1$ \\
\hline $\mathrm{Rb}$ & 311.6 & 0.5 & 82.4 & 131.6 & 102.3 & 103.5 & 199.7 & 0.6 & 69.5 & 70.15 \\
\hline $\mathrm{Hf}$ & 3.1 & $<0.1$ & 0.7 & 0.2 & 1.7 & 0.4 & 6 & $<0.1$ & 0.9 & 0.9 \\
\hline In & $<0.05$ & $<0.05$ & $<0.05$ & 0.16 & $<0.05$ & 0.11 & 0.14 & $<0.05$ & 0.06 & 0.05 \\
\hline $\operatorname{Re}$ & $<0.005$ & $<0.005$ & 0.006 & $<0.005$ & $<0.005$ & $<0.005$ & $<0.005$ & $<0.005$ & $<0.005$ & $<0.005$ \\
\hline $\mathrm{Se}$ & $<1$ & $<1$ & $<1$ & $<1$ & $<1$ & $<1$ & $<1$ & $<1$ & $<1$ & $<1$ \\
\hline $\mathrm{Te}$ & $<0.5$ & $<0.5$ & $<0.5$ & $<0.5$ & $<0.5$ & $<0.5$ & $<0.5$ & 4.9 & 1.1 & 1.5 \\
\hline $\mathrm{Ti}$ & 0.5 & $<0.5$ & 0.5 & 0.7 & 0.7 & - & 0.9 & $<0.5$ & $<0.5$ & $<0.5$ \\
\hline
\end{tabular}


From the results of the trace elements analyzed it can be deduced that the concentration of gold is very low $(<0.1)$ in all the rocks analysed but its pathfinder elements revealed gold showings in the study area. The variations plots of $\mathrm{SiO}_{2}$ against $(\mathrm{Pb}, \mathrm{Zn}, \mathrm{Cu}$ and $\mathrm{Br})$ is presented in Figure 11. The plots revealed the variability of the chemical composition of the rocks with respect to silica. This revealed that a single source material can produce over time, different rock types with variable chemical composition.

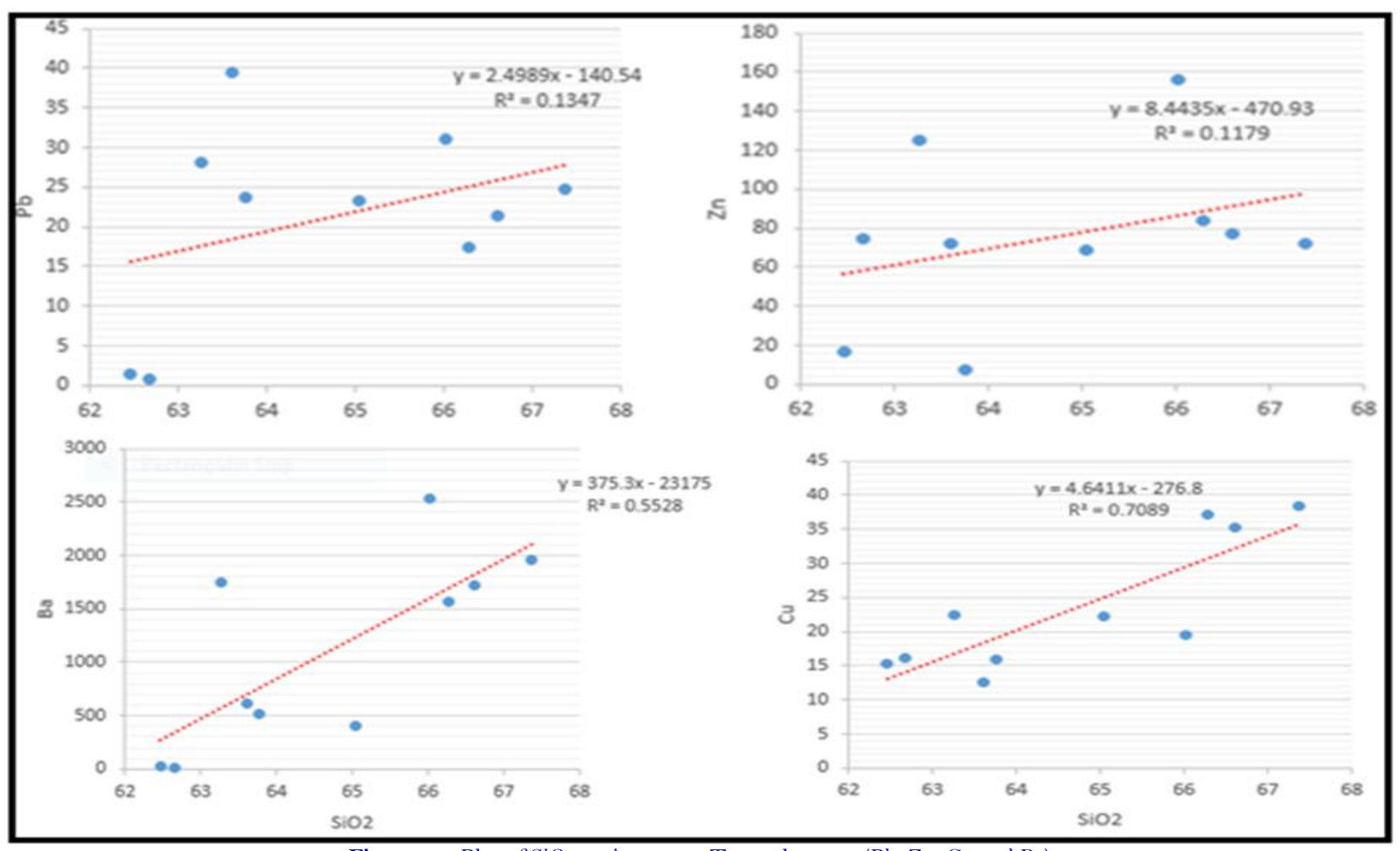

Figure 11. Plot of $\mathrm{SiO}_{2}$ against some Trace elements $(\mathrm{Pb}, \mathrm{Zn}, \mathrm{Cu}$ and $\mathrm{Br})$.

\subsubsection{Factor Analysis}

Factor analysis presents the elemental association which gives clue to possible mineralization in the study area Table 4. Group 1 consists of $\mathrm{Cu}-\mathrm{Pb}-\mathrm{Zn}-\mathrm{Mn}-\mathrm{Fe}-$ elemental associations with $32.24 \%$ variance of the total. However, there is likelihood of $\mathrm{Cu}, \mathrm{Pb}, \mathrm{Zn}, \mathrm{Mn}, \mathrm{Fe}$ mineralization in the study area. This is an indication of sulphide mineralization

Group 11 and 111 consist of $\mathrm{Pb}--\mathrm{Mn}-\mathrm{As}-\mathrm{Zr}$ element association which could be pathfinder element to the mineralization that characterize the study area with a variance of $24.74 \%$ of the total.

Group $1 \mathbf{V}$ and $\mathbf{V}$ consist of, As and Yr which is in minute concentrations.

\subsubsection{Enrichment Factor (EF) of Metals in the Study Area}

The Enrichment factor (EF) in metal is one of the indicators used to assess the presence and intensity of anthropogenic contaminant deposition on the rocks/soil. The percentage of enrichment factor (EF) revealed that $\mathrm{Zn}, \mathrm{Pb}$ and $\mathrm{Fe}$ are of moderate enrichment in the study area, which are hosted by the quartzites, quartz schists and migmatitic rocks in the study area; this may also be an indication of sulphide mineralization in the study area. Figure 12 showed the bar chart of distribution of metals contents in the rock samples of the study area while Table 5 summarized in percentage for individual metal and the number of locations that fell into the category of Enrichment. $\mathrm{Cu}, \mathrm{Mn}$ and $\mathrm{As}$ are (100\%)and are within deficiency to mineral Enrichment while. $\mathrm{Pb}, \mathrm{Zn}, \mathrm{Co}, \mathrm{Fe}, \mathrm{Th}$ and $\mathrm{Rb}$ metals fell within moderate Enrichment (20\%) and $\mathrm{Cr}$ have very high Enrichment. Therefore, $\mathrm{Cu}, \mathrm{Mn}$ and As are Deficiency to Mineral Enrichment. While Pb, Zn, Co, Fe, Th and Rb are of Moderate Enrichment. Only Cr 
is of very high Enrichment. The result also revealed that $\mathrm{Pb}, \mathrm{Zn}$, and $\mathrm{Co}$, that are moderately enriched in the migmatite-gneiss, quartzite, quartz schist and porphyritic granite rocks of the study area which also confirm sulphide mineralization in the study area.

Table 4. Factor analysis result.

\begin{tabular}{l|c|c|c|c|c|c}
\hline Variables & Comp 1 & Comp 1 & Comp 11 & Comp 1V & Comp V & Communalities \\
\hline $\mathrm{Cu}$ & 0.761 & & & & & 0.920 \\
\hline $\mathrm{Pb}$ & 0.562 & 0.700 & 0.267 & & & 0.930 \\
\hline $\mathrm{Zn}$ & 0.656 & 0.302 & & & & 0.924 \\
\hline $\mathrm{Co}$ & & & & 0.553 & & 0.910 \\
\hline $\mathrm{Mn}$ & 0.772 & & 0.321 & 0.136 & & 0.913 \\
\hline $\mathrm{Fe}$ & 0.778 & & & 0.195 & & 0.986 \\
\hline $\mathrm{As}$ & & 0.435 & 0.219 & 0.563 & 0.585 & 0.908 \\
\hline $\mathrm{Rb}$ & & 0.551 & 0.739 & & & 0.973 \\
\hline $\mathrm{Ni}$ & 0.586 & & & & & 0.866 \\
\hline $\mathrm{Yr}$ & 0.513 & 0.623 & & 0.202 & & 0.958 \\
\hline $\mathrm{Zr}$ & 0.487 & 0.674 & & 0.117 & & 0.924 \\
\hline $\mathrm{Mo}$ & 0.260 & 0.252 & 0.013 & & 0.751 & 0.941 \\
\hline $\mathrm{Al}$ & 0.922 & & 0.324 & 0.124 & 0.048 & 0.988 \\
\hline $\mathrm{Na}$ & 0.772 & 0.098 & 0.601 & 0.078 & 0.136 & 0.991 \\
\hline $\mathrm{EV}$ & 4.93 & 3.46 & 2.25 & 1.34 & 1.16 & \\
\hline $\mathrm{VAR}(\%)$ & 35.24 & 24.74 & 16.09 & 9.55 & 8.25 & \\
\hline $\mathrm{CVAR}(\%)$ & 35.24 & 59.98 & 76.07 & 85.62 & 93.87 & \\
\hline Note: COMP=Components (group of element association; VAR=Variance; CVAR=Covariance; \%=Percentage
\end{tabular}

Table 5. Distribution of metal content in the rock samples of the study area.

\begin{tabular}{|c|c|c|c|c|c|}
\hline Class & $\mathrm{EF}<2$ & $\mathrm{EF}=2-5$ & $\mathrm{EF}=5-20$ & $\mathrm{EF}=20-40$ & $\mathrm{EF}>40$ \\
\hline $\begin{array}{l}\text { Heavy } \\
\text { Metals }\end{array}$ & $\begin{array}{l}\text { Deficiency to } \\
\text { Mineral Enrichment }\end{array}$ & $\begin{array}{l}\text { Moderate } \\
\text { Enrichment }\end{array}$ & $\begin{array}{l}\text { Significant } \\
\text { Enrichment }\end{array}$ & Very High & $\begin{array}{l}\text { Extremely } \\
\text { High Enrichment }\end{array}$ \\
\hline $\mathrm{Pb}$ & 80 & 20 & $\mathrm{O}$ & $\mathrm{O}$ & $\mathrm{O}$ \\
\hline $\mathrm{Zn}$ & 80 & 20 & $\mathrm{O}$ & $\mathrm{O}$ & $\mathrm{O}$ \\
\hline $\mathrm{Fe}$ & 90 & 10 & $\mathrm{O}$ & $\mathrm{O}$ & 0 \\
\hline As & 100 & $\mathrm{O}$ & $\mathrm{O}$ & $\mathrm{O}$ & 0 \\
\hline $\mathrm{Th}$ & 80 & 20 & $\mathrm{O}$ & $\mathrm{O}$ & $\mathrm{O}$ \\
\hline $\mathrm{Cr}$ & 80 & 10 & $\mathrm{O}$ & $\mathrm{O}$ & $\mathrm{O}$ \\
\hline
\end{tabular}

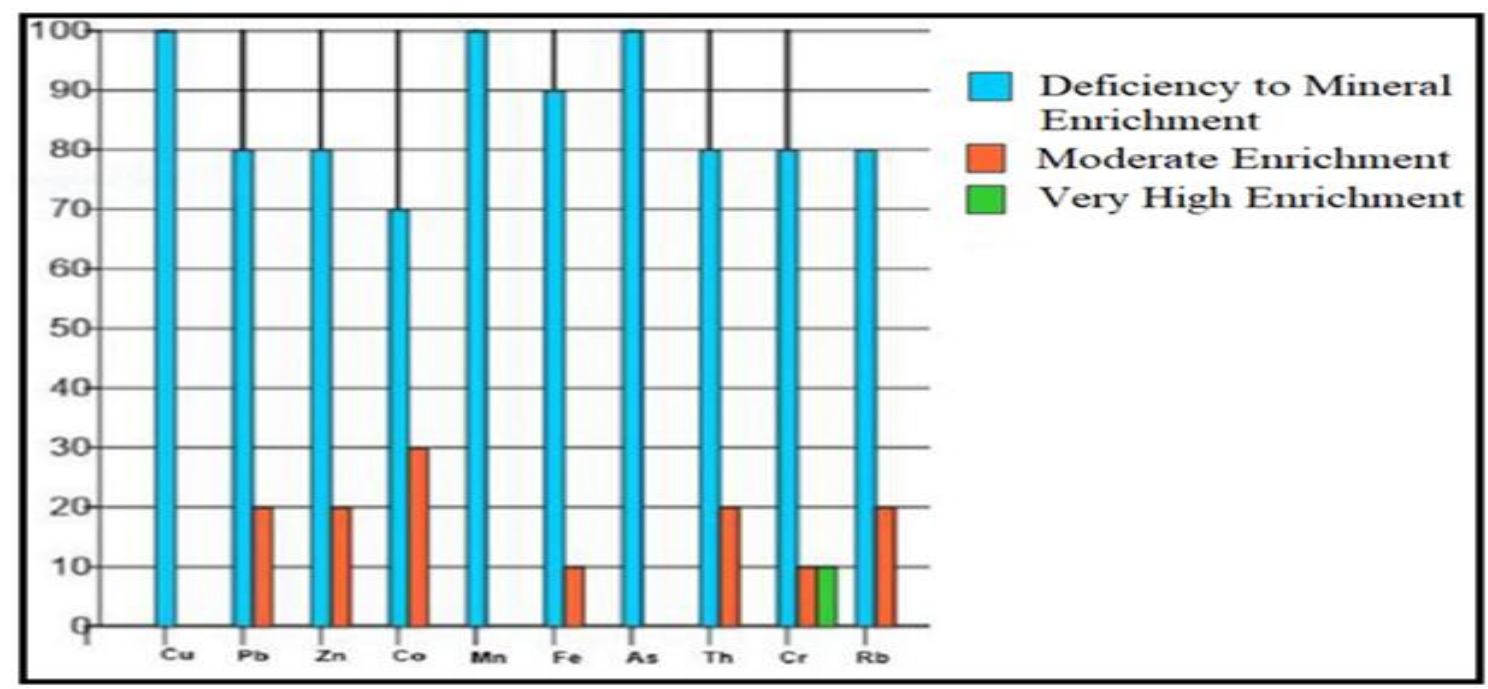

Figure 12. Distribution of metal contents in the rock sample of the study area. 


\subsection{Geochemical Anomaly for Radio Active Elements}

The descriptive statistics of the radioactive elements in the study area is presented in Table 6 while Figure 13 shows the anomalous plots. These results showed that levels of radio- active mineralization potentials in the study area. Radio-active elements such as $\mathrm{U}$, $\mathrm{Th}$ and $\mathrm{Rb}$ have higher concentration values far above the normal or background value to produce anomaly in the study area. U range Table 6 as (<0.1-6.3ppm), threshold (3.7), anomaly, $\mathrm{Rb}$ (.50-311.6ppm), threshold (199.7), anomaly (311.6) and Th (0-50.1ppm), threshold (28.5), anomaly (50.1). However, $(\mathrm{Pb})$ has a moderate value but could not produce anomaly. However, this can be correlated with the age of the granite as it yet to be matured for disintegration of radioactive isotopes to $\mathrm{Pb}$ as it is obvious that most of these elements have their higher concentration values mostly on the porphyritic granites present in the study area (Table 3). For instance, the porphyritic granite in Kristal quarry, Ipetu, where U has highest concentration values (6.3ppm), Th (30.5ppm) and $\mathrm{Rb}(102.3 \mathrm{ppm})$. Similarly, porphyritic granite in Oke Arifo ,IkejiIle where Th has its highest value (50.1ppm), U (2.6ppm)and Rb (199.7ppm). Also in Ogotun, Rb has its highest concentration value that produce anomalies in the migmatite gneiss of $\mathrm{Pa}$ Tunji compound consists of , Rb (311.6ppm), U (2.6ppm) and Th (1.5ppm) respectively. It is very clear from the results presented that these radioactive elements spread across the three communities in the study area. However, exposure to these elements could be harmful to human health, especially when people consumed water already polluted by these elements. Genetic mutation is also one of the inherent manifestation of these radioactive elements.

Table 6. Descriptive statistics for radioactive elements in the study area.

\begin{tabular}{l|c|c|c|c}
\hline Element & Minimum & Maximum & Threshold & Anomaly \\
\hline $\mathrm{Th}$ & $\mathrm{O}$ & 50.1 & 28.5 & 50.1 \\
\hline $\mathrm{Rb}$ & 0.50 & 311.60 & 199.7 & 311.6 \\
\hline $\mathrm{U}$ & $<0.1$ & 6.3 & 3.7 & 6.3 \\
\hline $\mathrm{Pb}$ & 0.9 & 39.4 & 39.4 & - \\
\hline
\end{tabular}

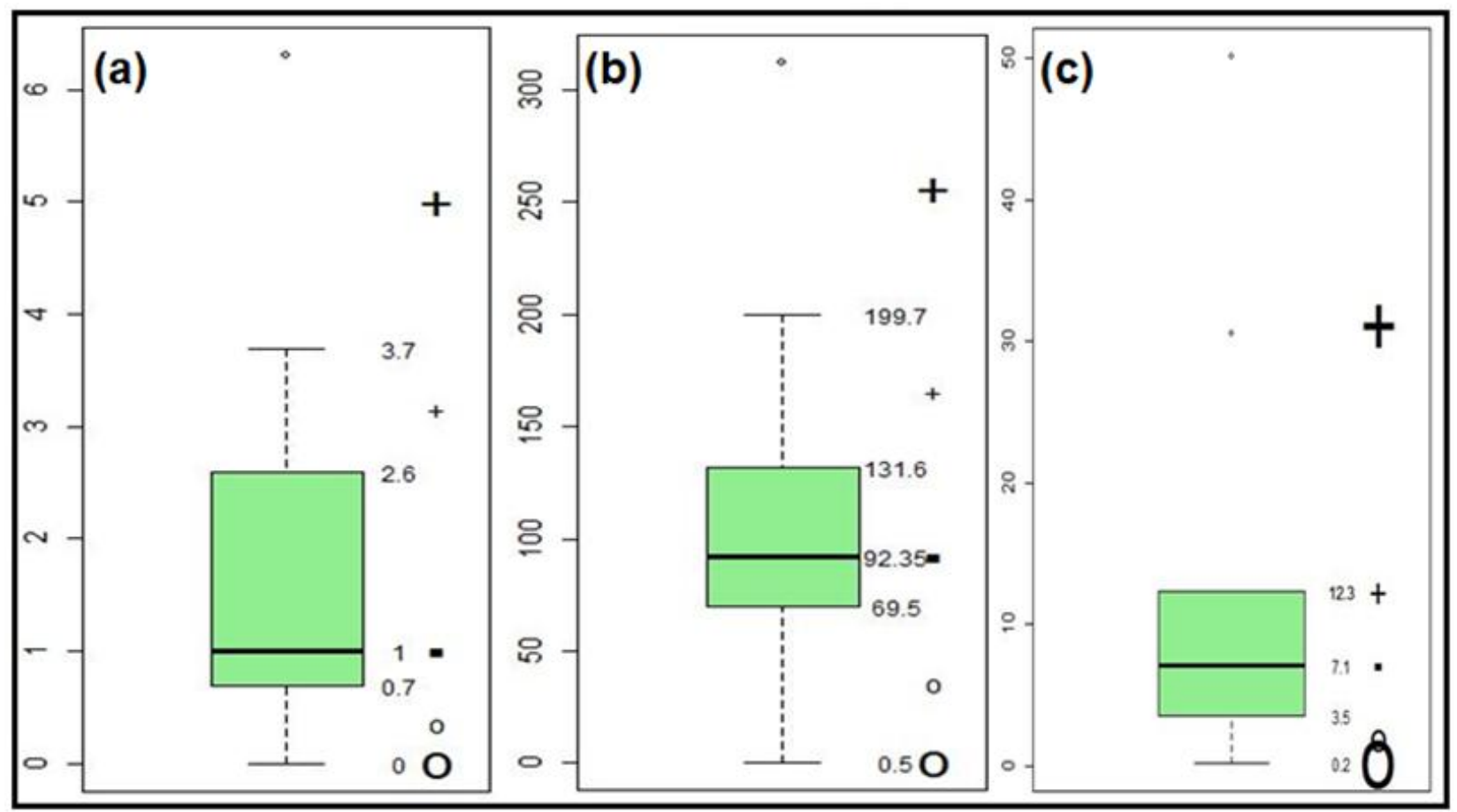

Figure 13. Anomaly plots of (a) Uranium, (b) Rubidium and (c) Thorium in the study area.

\section{CONCLUSION}

Geochemical characterization of meta-sedimentary rocks of Ogotun, Ikeji-Ile and Ipetu has provided the base line information about the lithological characteristic and metallic minerals concentration in the rocks which can 
serve as exploration guide for future researchers in the study area. The geological mapping of the study area revealed the disposition of the five lithologies identified: migmatite gneiss, quartzite, quartz-schists, metaconglomerate and porphyritic granite with well delineated boundaries. Also, the cross sectional map confirmed folding on the quartzites and quartz-schists which was recognized to be an antiform. Petrographic studies of all the thin section present revealed that the rocks are characterized by the assemblages of quartz, biotite, muscovite, plagioclase, microcline and opaque minerals. The five polished sections viewed under Ore microscope suggest the presence of a brassy yellow coloured mineral from the migmatite-gneiss and quartz-schist polished sections confirmed to be chalcopyrite $\left(\mathrm{CuFeS}_{2}\right)$. The geochemical analytical results confirmed the siliceous, feldspathic as well as the alumino-silicate nature of the investigated rocks. The trace element geochemistry revealed the abundance of $\mathrm{Ba}, \mathrm{Cu}, \mathrm{Pb}, \mathrm{Zn}, \mathrm{Co}, \mathrm{Pb}, \mathrm{Rb}, \mathrm{Li}$ which are reflections of the bedrock lithology and the nature of invading magma on the surrounding rocks. The factor analysis revealed $\mathrm{Cu}-\mathrm{Zn}-\mathrm{Fe}-\mathrm{Cu}-\mathrm{Mn}$, elemental association as the possible mineralization potentials in the studied while the calculated enrichment factors indicated $\mathrm{Pb}, \mathrm{Zn}$, $\mathrm{Co}, \mathrm{Fe}$ as having high enrichment. Also, $\mathrm{Th}, \mathrm{Rb}$ and $\mathrm{U}$, have anomalies suggesting that their concentration are far above background level, there by confirming the radioactive nature of the rocks.

The study area has been investigated for possible mineralization prospect, and it has been established that both metallic and radioactive minerals as well as other possibly, hidden ore deposits such as sulphide ores, smithsonite $(\mathrm{ZnS})$ and other associated mineral deposits of economic importance abound in the study area which further investigation will unravel using detailed geochemical and geophysical studies in conjunction with hyperspectral remote sensing.

Funding: This study received no specific financial support.

Competing Interests: The authors declare that they have no competing interests.

Authors' Contributions: All authors contributed equally to the conception and design of the study.

\section{REFERENCES}

Abiodun, E. A. (2011). Integrated geochemical and geophysical approach to mineral prospecting - a case study on the basement complex of Ilesa Area, Nigeria. Ile - Ife, Nigeria: Earth and Space Physics Research Laboratory, Department of Physics, Obafemi Awolowo University (OAU).

Ajayi, T. (1981). Statistical analysis of stream sediment data from the Ife-Ilesha area of South West Nigeria. Journal of Geochemical Exploration, 15(1-3), 539-548.Available at: https://doi.org/10.1016/0375-6742(81)90085-6.

Ajibade, A., Woakes, M., \& Rahaman, M. (1987). Proterozoic crustal development in the Pan-African regime of Nigeria. Proterozic Lithospheric Evolution, 17, 259-271.Available at: https://doi.org/10.1029/gdo17p0259.

Ajibade, A., \& Wright, J. (1989). The Togo-Benin-Nigeria Shield: evidence of crustal aggregation in the Pan-African belt. Tectonophysics, 165(1-4), 125-129.Available at: https://doi.org/10.1016/0040-1951(89)90041-3.

Ajibade, A. C., \& Wright, J. B. (1988). Structural relationships in the schist belts of North Western Nigeria. In: Oluyide, P.O., et al. (Eds.), Precambrian Geology of Nigeria (pp. 103-109). Kaduna: Geological Survey of Nigeria Publication.

Ayodele, O. S., Oshin, O. O., \& Awokunmi, E. E. (2017). Auriferous showings in the bedrocks and stream sediments of OkemesiIjero Area, Southwestern Nigeria. American Journal of Earth Sciences, 4(2), 8-31.

Bafor, B. E. (1988). Some geochemical considerations in the evolution of the Nigerian basement in the Egbe area of Southwestern Nigeria. In: Oluyide, P.O., et al. (Eds.), Precambrian Geology of Nigeria (pp. 277-288): Geological Survey of Nigeria Publications.

Burke, K. C. (1972). Orogeny in ric, in esauvage. T.F.J and Whiteman, A.J (Eds) (pp. 583-608): African Geology-University of Ibadan.

Dada, S., \& Rahaman, M. (1995). Archaean-lower proterozoic crustal evolution in Nigeria. Africa Geoscience Review, 2(2), 219225. 
Elueze, A. (1981). Geochemistry and petrotectonic setting of metasedimentary rocks of the schist belt of Ilesa area, southwestern Nigeria. Nigeria Journal of Mining and Geology, 18(1), 194-197.

Elueze, A. A. (1988). Geology of the precambrian schist belt in llesha area, South Western Nigeria. In: Oluyide, P.O., et al. (Eds.), Precambrian Geology of Nigeria (pp. 77-89): Geological Survey of Nigeria.

Frost, C., Frost, B., Chamberlain, K., \& Edwards, B. (1999). Petrogenesis of the 1.43 Ga Sherman batholith, SE Wyoming, USA: A reduced, rapakivi-type anorogenic granite. Journal of Petrology, 4O(12), 1771-1802.Available at: https://doi.org/10.1093/petroj/40.12.1771.

Grant, N. K. (1969). The late precambrian to early paleozoic orogeny in Ghana, Togo, Dahomey and Nigeria. Geological Survey of American Bulletin, 80(1), 45-56.

Hubbard, F. H. (1975). Precambrian crustal development in western Nigeria: Indications from the Iwo region. Geological Society of America Bulletin, 86(4), 548-554.Available at: https://doi.org/10.1130/00167606(1975)86\%3C548:pcdiwn\%3E2.0.co;2.

McCurry, P. (1973). Geology of degree sheet 21, Zaria, Nigeria. Overseas Geology and Mining Resources, No. 45, H.M.S.O. London.

Nigeria Geological Survey Agency. (1963). Topographic Map sheets 243 and 244, Edition.

Odeyemi, I. (1993). A comparative study of remote sensing images of the structure of the Okemesi Fold Belt, Nigeria. ITC Journal, 1993-1, 77-81.

Ojo, O. (1988). Stream sediment geochemistry of Guberunde Horst,“Gongola basin”, Upper Benue Trough, Nigeria. Journal of African Earth Sciences (and the Middle East), 7(1), 91-101.Available at: https://doi.org/10.1016/0899-5362(88)90055-3.

Olarewaju, V. O. (1988). Petrology and geochemistry of the charnockitic and associated granitic rocks of Ado-Ekiti-Akure Southwestern Nigeria In: Precambrian Geology of Nigeria (pp. 231-239): Geological Survey of Nigeria Publications.

Onougu, B. A., \& Ferrante, M. C. (1965). Geochemical orientation study in the Ife-Ilesha Area of Western Nigeria (pp. 15). Geological Survey of Nigeria Report. No.1417.

Oyawoye, M. O. (1972). The basement complex of Nigeria. In: Dessauvage, T.F.J and Whiteman, A.J.W (Eds) (pp. 66-102): University of Ibadan.

Rahaman, M. A. (1988). Recent advances in the study of the basement complex of Nigeria: Precambrian Geology of Nigeria (pp. 11-41): Geological Survey of Nigeria.

Turner, D. (1983). Upper proterozoic schist belts in the Nigerian sector of the Pan-African province of West Africa. Precambrian Research, 21(1-2), 55-79.Available at: https://doi.org/10.1016/0301-9268(83)90005-0.

Views and opinions expressed in this article are the views and opinions of the author(s), International Journal of Geography and Geology shall not be responsible or answerable for any loss, damage or liability etc. caused in relation to/arising out of the use of the content. 